\title{
Revised stratigraphy of Neogene strata in the Cocinetas Basin, La Guajira, Colombia
}

Moreno, F ; Hendy, A J W ; Quiroz, L ; Hoyos, N ; Jones, D S ; Zapata, V ; Zapata, S ; Ballen, G A ;

Cadena, E ; Cárdenas, A L ; Carrillo-Briceño, J D ; Carrillo, J D ; Delgado-Sierra, D ; Escobar, J ;

Martínez, J I ; Martínez, C ; Montes, C ; Moreno, J ; Pérez, N ; Sánchez, R ; Suárez, C ; Vallejo-Pareja, M C ; Jaramillo, C

DOI: https://doi.org/10.1007/s13358-015-0071-4

Posted at the Zurich Open Repository and Archive, University of Zurich

ZORA URL: https://doi.org/10.5167/uzh-110320

Journal Article

Accepted Version

Originally published at:

Moreno, F; Hendy, A J W; Quiroz, L; Hoyos, N; Jones, D S; Zapata, V; Zapata, S; Ballen, G A; Cadena, E; Cárdenas, A L; Carrillo-Briceño, J D; Carrillo, J D; Delgado-Sierra, D; Escobar, J; Martínez, J I; Martínez, C; Montes, C; Moreno, J; Pérez, N; Sánchez, R; Suárez, C; Vallejo-Pareja, M C; Jaramillo, C (2015). Revised stratigraphy of Neogene strata in the Cocinetas Basin, La Guajira, Colombia. Swiss Journal of Palaeontology, 134(1):5-43.

DOI: https://doi.org/10.1007/s13358-015-0071-4 


\title{
Revised stratigraphy of Neogene strata in the Cocinetas Basin, La Guajira, Colombia
}

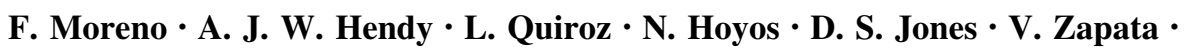 \\ S. Zapata $\cdot$ G. A. Ballen $\cdot$ E. Cadena $\cdot$ A. L. Cárdenas $\cdot$ J. D. Carrillo-Briceño $\cdot$ \\ J. D. Carrillo · D. Delgado-Sierra · J. Escobar · J. I. Martínez • C. Martínez • C. Montes • \\ J. Moreno $\cdot$ N. Pérez $\cdot$ R. Sánchez $\cdot$ C. Suárez $\cdot$ M. C. Vallejo-Pareja $\cdot$ C. Jaramillo
}

Received: 25 September 2014/ Accepted: 2 February 2015

(C) Akademie der Naturwissenschaften Schweiz (SCNAT) 2015

\begin{abstract}
The Cocinetas Basin of Colombia provides a valuable window into the geological and paleontological history of northern South America during the Neogene. Two major findings provide new insights into the Neogene history of this Cocinetas Basin: (1) a formal re-description of the Jimol and Castilletes formations, including a revised contact; and (2) the description of a new lithostratigraphic unit, the Ware Formation (Late Pliocene). We conducted extensive fieldwork to develop a basin-scale stratigraphy,
\end{abstract}

Electronic supplementary material The online version of this article (doi:10.1007/s13358-015-0071-4) contains supplementary material, which is available to authorized users.

F. Moreno $\cdot$ L. Quiroz · N. Hoyos · V. Zapata · S. Zapata ·

G. A. Ballen - E. Cadena - A. L. Cárdenas .

J. D. Carrillo-Briceño · J. D. Carrillo · J. Escobar .

C. Martínez · J. Moreno · N. Pérez · R. Sánchez · C. Suárez ·

M. C. Vallejo-Pareja · C. Jaramillo

Smithsonian Tropical Research Institute, Panamá, USA

F. Moreno · N. Hoyos · A. L. Cárdenas

Corporación Geológica ARES, Bogotá, Colombia

F. Moreno $(\bowtie)$

University of Rochester, Rochester, NY, USA

e-mail: federicomrn@gmail.com

A. J. W. Hendy

Natural History Museum of Los Angeles County,

Los Angeles, CA, USA

A. J. W. Hendy · D. S. Jones

Florida Museum of Natural History, Gainesville, FL, USA

L. Quiroz

University of Saskatchewan, Saskatoon, Canada

N. Hoyos · A. L. Cárdenas · J. Escobar

Universidad del Norte, Barranquilla, Colombia made exhaustive paleontological collections, and performed ${ }^{87} \mathrm{Sr} /{ }^{86} \mathrm{Sr}$ geochronology to document the transition from the fully marine environment of the Jimol Formation (ca. 17.9-16.7 Ma) to the fluvio-deltaic environment of the Castilletes (ca. 16.7-14.2 Ma) and Ware (ca. 3.5-2.8 Ma) formations. We also describe evidence for short-term periodic changes in depositional environments in the Jimol and Castilletes formations. The marine invertebrate fauna of the Jimol and Castilletes formations are among the richest yet recorded from Colombia during the Neogene. The Castilletes and Ware formations have also yielded diverse and biogeographically significant fossil vertebrate assemblages. The revised lithostratigraphy and

V. Zapata

Ecopetrol S.A., Bogotá, Colombia

E. Cadena

Senckenberg Museum, Frankfurt, Germany

J. D. Carrillo-Briceño $\cdot$ J. D. Carrillo

Paleontological Institute and Museum, University of Zurich,

Zurich, Switzerland

D. Delgado-Sierra · J. I. Martínez

Universidad Eafit, Medellín, Colombia

C. Martínez

Cornell University, Ithaca, NY, USA

C. Montes · N. Pérez

Universidad de los Andes, Bogotá, Colombia

J. Moreno

University of Nebraska-Lincoln, Lincoln, NE, USA

C. Suárez

Museo de la Plata, La Plata, Argentina 
chronostratigraphy presented here provides the necessary background information to explore the complete evolutionary and biogeographic significance of the excellent fossil record of the Cocinetas Basin.

Keywords Stratigraphy · Paleontology ·

Paleoenvironments · GABI (Great American Biotic Interchange) $\cdot$ Miocene $\cdot$ Pliocene $\cdot$ Cocinetas Basin $\cdot$ La Guajira Peninsula $\cdot$ Colombia

\section{Introduction}

Cenozoic pull-apart sedimentary basins are common along the northern edge of the South American continent as a consequence of the interaction between the South American and Caribbean plates (Muessig 1984; Pindell 1991; Zapata et al. 2014). One such sedimentary basin is
Cocinetas, which is located on the eastern flank of $\mathrm{La}$ Guajira Peninsula, northern Colombia (Fig. 1). The Cocinetas Basin provides an extensive and well-exposed sedimentary and paleontological record of the past 30 million years.

There are very few geologic studies of the Cocinetas Basin. The stratigraphy was first described by Renz (1960), who proposed the formal names, stratotypes, depositional environments, and ages for the various units of the basin (Figs. 1 and 2). Rollins (1965) carried out further detailed descriptions redefining a number of stratigraphic units (Fig. 2). Biostratigraphic data based on micropaleontology (Becker and Dusenbury 1958; Burgl 1960; Lockwood 1965; Renz 1960; Rollins 1965; Zapata 2010) and macropaleontology (Olsson and Richards 1961; Rollins 1965; Thomas 1972) have been previously reported. However, most of these studies are taxonomically outdated, lack of systematic analysis, and are based on

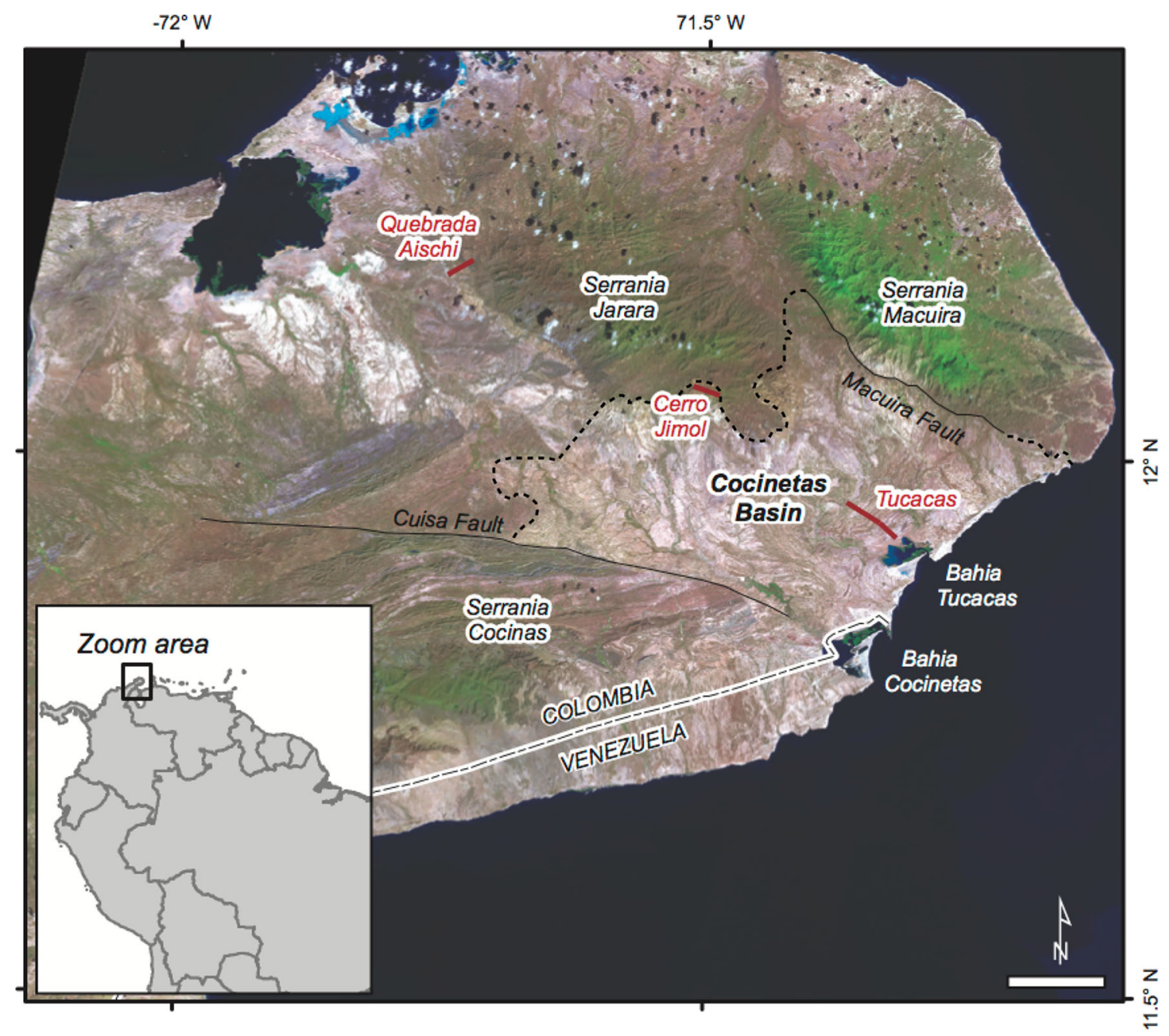

Fig. 1 Regional location of Cocinetas Basin flanked by the Serranías of Cocinas, Jarara and Macuira, in the northern Guajira Peninsula of Colombia, South America. Stratotypes defined by Renz (1960) are shown in red. Image from Landsat 8 OLI-TIRS sensor acquired on January 10, 2014 (RGB 543). Scale bar is $10 \mathrm{~km}$ 


\begin{tabular}{|c|c|c|c|c|c|c|c|c|}
\hline \multicolumn{8}{|c|}{ Cocinetas Basin } & \multirow{2}{*}{$\begin{array}{c}\text { Falcon Basin } \\
\begin{array}{c}\text { Jaramillo } \\
\text { \& Quiroz } \\
\text { (2012) }\end{array}\end{array}$} \\
\hline$\frac{\pi}{4}$ & $\begin{array}{l}\text { 믐 } \\
\frac{0}{0} \\
0\end{array}$ & \multicolumn{2}{|c|}{ Epoch } & $\begin{array}{c}\text { Renz } \\
(1960)\end{array}$ & $\begin{array}{l}\text { Rollins } \\
(1965)\end{array}$ & This Work & 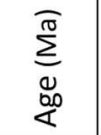 & \\
\hline \multirow{11}{*}{$\begin{array}{l}\frac{U}{0} \\
\text { N } \\
\text { Oุ } \\
\text { U }\end{array}$} & \multirow{7}{*}{ 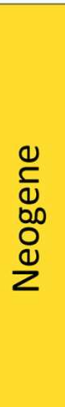 } & نं & Late & & \multirow{3}{*}{ Castilletes } & Ware & \multirow{4}{*}{$\sim 3.5$} & San Gregorio \\
\hline & & $\stackrel{\bar{a}}{a}$ & Early & & & & & Codore \\
\hline & & \multirow{5}{*}{ 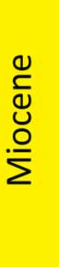 } & Late & \multirow{5}{*}{ Tucacas } & & & & Urumaco \\
\hline & & & \multirow{2}{*}{ Middle } & & \multirow{2}{*}{ Jimol } & & & Socorro \\
\hline & & & & & & Castilletes & \multirow{3}{*}{$\begin{array}{r}-14.2 \\
-16.7 \\
-17.9\end{array}$} & Querales \\
\hline & & & \multirow{2}{*}{ Early } & & \multirow{3}{*}{ Uitpa } & Jimol & & Cerro Pelao \\
\hline & & & & & & Uitpa & & Agua Clara \\
\hline & \multirow{4}{*}{ 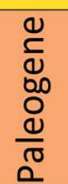 } & \multirow{4}{*}{$\begin{array}{l}\text { थ } \\
\frac{1}{0} \\
\text { D } \\
.000 \\
\frac{.00}{0}\end{array}$} & Late & Jimol & & \multirow{4}{*}{ Siamana } & & \\
\hline & & & Middle & Uitpa & \multirow{3}{*}{ Siamana } & & & \\
\hline & & & IVIradie & Siamana & & & & \\
\hline & & & Early & & & & & \\
\hline
\end{tabular}

Fig. 2 Historical stratigraphic nomenclature for the Cocinetas Basin, La Guajira, Colombia. Gray color indicates intervals where sediment was not preserved

paleontological collections of variable quality. A review of macropalaeontological evidence for the age of the Neogene units of the Cocinetas Basin is provided by Hendy et al. (2015) in this issue.

Over the past 4 years, we have conducted extensive fieldwork in the Cocinetas Basin, including geological mapping, lithofacies descriptions, and extensive and systematic collection of microfossils, marine and terrestrial invertebrates, marine and terrestrial vertebrates, and plants. Here, we provide a revised stratigraphy for the Neogene of the Cocinetas Basin, including a redefinition of the Jimol and Castilletes formations, and the description of a new lithostratigraphic unit, namely the Ware Formation (Pliocene). In addition we present a chronostratigraphic framework that is supported by ${ }^{87} \mathrm{Sr} /{ }^{86} \mathrm{Sr}$ isotopic analyses and marine invertebrate biostratigraphy, and a paleoenvironmental interpretation of the sedimentary succession.

\section{Geological setting}

Since the Late Eocene, the northern margin of the South American plate has been affected by right-lateral transpressive tectonism caused by its oblique convergence with the southern margin of the Caribbean plate (Macellari 1995; Pindell and Barret 1990; Zapata et al. 2014). This interaction has caused the fragmentation and eastward migration of several South American blocks including the Paraguaná, Falcon, Maracaibo, Guajira, Perijá, and Santa Marta, and the subsequent opening of pull-apart sedimentary basins along the northern margin of South America, e.g., Cocinetas, Chichibacoa, Falcon, La Vela, and Paraguaná (Macellari 1995; Muessig 1984; Zapata et al. 2014).

The Cocinetas Basin located in the Guajira Peninsula is bounded by the Cocinas, Jarara, and Macuira ranges (Fig. 1). Sedimentation in the basin started during the middle-late Eocene (Macarao Formation) and continued again during the Late Oligocene (Siamana Formation), with a sequence of conglomerates and thick carbonates (Fig. 2) (Macellari 1995; Renz 1960). Overlying the Siamana Formation is the Early Miocene Uitpa Formation, a thick sequence of calcareous mudstone interbedded with lithic sandstones (Renz 1960; Rollins 1965). Overlying the Uitpa Formation are the Miocene Jimol and Castilletes formations (Fig. 2), composed mostly of lithic sandstones and mudstones, which can be highly fossiliferous. The last phase of preserved sedimentation is represented by the Pliocene Ware Formation, a new formation formally proposed herein.

\section{Former lithostratigraphic definition of Neogene units}

Renz (1960) formally described the Siamana, Uitpa, Jimol, and Tucacas formations (Fig. 2). Rollins (1965) formally named the Macarao Formation; redefined the Siamana, Uitpa, and Jimol formations; proposed the name Castilletes as a replacement for the Tucacas Formation; and redefined ages and areal distribution for these units (Fig. 2). It should 
be noted that Renz (1960) named the Jimol Formation after Cerro Jimol located to the southeast of the Jarara Range and proposed its stratotype in Quebrada Aischi (Fig. 1), outside the boundaries of the Cocinetas basin. Rollins (1965) had a different opinion, and assigned both the Quebrada Aischi and Cerro Jimol sections as belonging to the Siamana Formation. He redefined the areal distribution in some problematic areas as Cerro Jimol and Quebrada Aischi, but accepted the general distribution proposed by Renz (1960). Without defining a new stratotype, he described the Jimol Formation as the sandy limestone, calcareous sandstone, and clay overlying the softer sediments of the Uitpa Formation and underlying the Ostrea-bearing limestone at the base of the Castilletes Formation. Rollins (1965) reported a thickness of $614 \mathrm{~m}$ for the Jimol Formation and assigned a Middle Miocene age based on the molluskan assemblage of Clementia dariena, Cardium gatunese, Arca chiriquiensis bolivari, Arca grandis colombiensis, and Turritella aff. supraconcava. While these 'species' are largely supportive of a Late Miocene age (following current biostratigraphic knowledge), the identifications and interpretation of Rollins (1965) need to be revised. A review of macropalaeontological evidence for the age of the Neogene units of the Cocinetas Basin is provided by Hendy et al. (2015) in this issue. The foraminiferal biotas that occur in the lower and upper parts of the Jimol Formation are associated with the Miogypsina günteri and the Miogypsina intermedia biozones (Renz 1960). These assemblages were initially reported as indicating a middle to Late Oligocene age (Renz 1960). However, identification of Globorotalia semivera (Hornibrook) (=Paragloborotalia semivera) by $\mathrm{H}$. Duque Caro from the Jimol Formation (Zapata 2010) supports a Late Early Miocene age (Chaisson and D'Hondt 2000).

The Jimol Formation is overlying conformably by the Castilletes Formation, which is composed mostly of wackestone and packstone biosparite, and fossiliferous sandstone and mudstone. Renz (1960) first named this unit the Tucacas Formation after Bahía Tucacas. However, Rollins (1965) argued that the name Tucacas was likely to create confusion because of the presence of a town of the same name, located in northern Venezuela. Rollins (1965), therefore, re-erected the presently used name, Castilletes Formation, after the village of Castilletes, located in $\mathrm{La}$ Guajira Peninsula. Rollins, however, retained the type section proposed by Renz for the Tucacas Formation, which is located in the area of Bahía Tucacas (Fig. 1). Renz (1960) reported a thickness of 800 to $900 \mathrm{~m}$ at the type section, whereas Rollins (1965) measured the section again and estimated a thickness of $692 \mathrm{~m}$, listing Ostrea pulchana, Chlamys (Aequipecten) plurinomis morantensis, and Pecten bowdenensis among other taxa collected at the stratotype. Renz (1960) dated the base of the Formation as earliest Miocene based on the larger foraminifer Miogypsina antillea. Rollins (1965), however, accepted that none of the macrofauna collected were diagnostic for age, although they seem to suggest a Pliocene age (following current biostratigraphic knowledge). As noted above, Rollins's (1965) identifications and interpretation are in doubt and are critically assessed by Hendy et al. (2015) in this issue. Rollins (1965 p. 59) agreed with Renz (1960) that the base of the Castilletes was in the Miocene, but argued that the top of the unit was Pliocene on the basis of its stratigraphic position (Fig. 2). A diverse foraminiferal assemblage from the lower part of the Castilletes Formation has been described (Burgl 1960), including the planktonic foraminifera Globigerina trilocularis, Globigerinoides rubra, Globigerinoita morugaensis, Globorotalia mayeri, and Globorotalia praemenardii. Of these, G. mayeri (=Paragloborotalia mayeri) and $G$. praemenardii (=Menardella praemenardii) are presently regarded as indicative of the early Late Miocene (Chaisson and D'Hondt 2000; Rincón et al. 2007).

\section{Methods}

We carried out extensive geological mapping aided by analysis of high-resolution satellite imagery to improve or determine the location of contacts and areal distribution of the Jimol, Castilletes, and Ware Formations. This process was facilitated by the landscape, in part because the region is very dry and strata are well exposed and easily seen in satellite imagery. The geologic map of Irving (1971) was used as the base map. Initial field mapping identified units by their lithology and topographic expression. We controlled boundaries between units with transects along both the strike and the dip. The field map was refined with satellite imagery from multiple sensors (Table 1). Multiple band ratios from Aster and Landsat imagery were calculated and different combinations were displayed as RGB to aid in the delineation of specific lithologies (Qari et al. 2008; Rawashdeh et al. 2006; Schetselaar et al. 2007; Van der Meer et al. 2012). We used high-resolution imagery (GeoEye-1) during subsequent expeditions to improve the field map. Edge analysis was performed to highlight features such as lineaments (mostly in the NE direction) and areas with vegetation, which are usually within specific geologic units (i.e., coquinas and alluvial plains). Lineaments, faults, geologic unit contacts, and beds from previous maps were then updated through a visual assessment of imagery products. The final geologic map also includes field localities and the geographic start and end points of the new stratigraphic sections. All field data, including fossil collection sites, structural data, and stratigraphic sections, were recorded using global positioning system 
Table 1 Relevant characteristics of satellite imagery used for geologic mapping

\begin{tabular}{llll}
\hline Sensor & Date $($ yyyy $/ \mathrm{mm} / \mathrm{dd})$ & Spatial resolution $(\mathrm{m})$ & Products generated \\
\hline Landsat ETM+1 & $3 / 3 / 2001$ & 30 (Blue, green, red, & Band ratios \\
& & NIR, SWIR) & \\
& & 15 (Panchromatic) & \\
Aster & $15($ Green, red, NIR) & Band ratios \\
& $30($ SWIR) & \\
Geoeye-1 & $7 / 3 / 2007$ & $2(\text { Blue, green, red, NIR })^{2}$ & PCA $^{3}$, edge analysis, unsupervised \\
& & 0.5 (Panchromatic) & classification \\
\hline
\end{tabular}

\section{A}

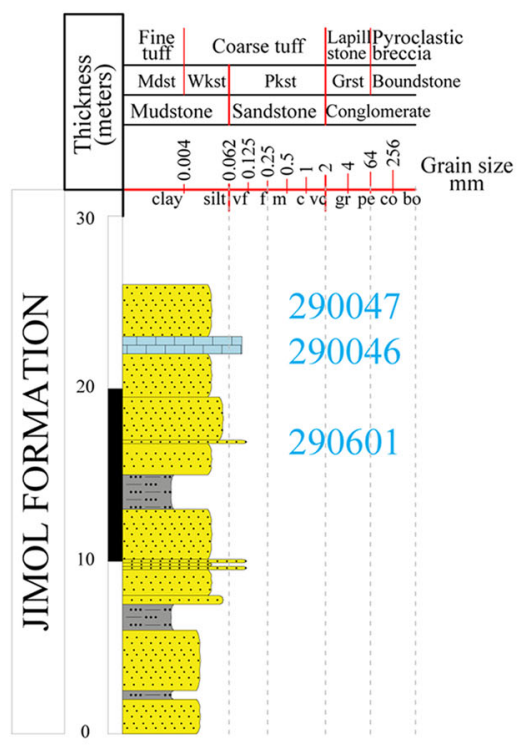

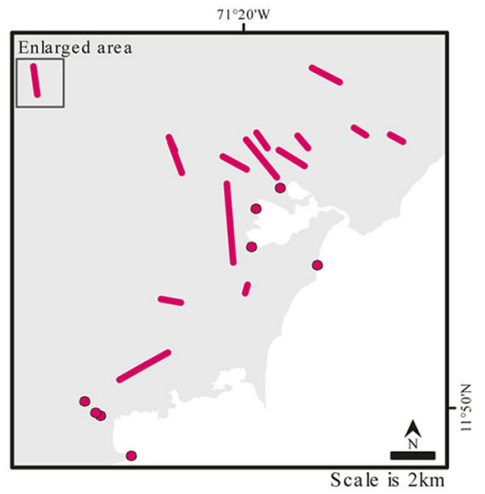

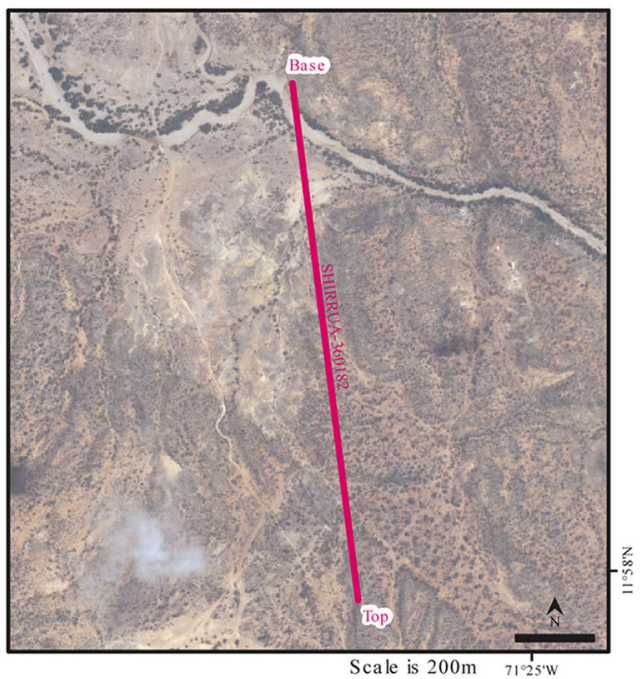

Locality 430169; 1 Long, Locality 150514; m Topio Este, Locality 290825 and Topio Oeste, Locality 430170; n Shavo, Locality 430200; o Puerto López Sureste, Locality 290609; p Bahía Tucacas Norte, Locality 430115; Bahía Tucacas Medio, Locality 430116 and Bahía Tucacas Sur, Locality 430117; q Punta Gorda Sur-290617; r Padsua Este, Locality 430112; Padsua Sur, Locality 430113 and Padsua Norte-430205; s Punta Gorda Norte, Locality 430102; t Estacion De Policia, Locality 430052; u Bahía Cocinetas, Locality 430120

Twenty-six stratigraphic sections were measured (Fig. 3) and correlated using fieldwork observations, macrofaunal composition, and the results of ${ }^{87} \mathrm{Sr} /{ }^{86} \mathrm{Sr}$
(GPS) units. Image processing was performed with IDRISI Selva (Clark Labs), and vector editing and assemblage of map products were carried out in ArcGIS v 10.0 (ESRI).
Fig. 3 Stratigraphic sections measured and described in the Cocinetas basin. In each figure the upper map shows the location of the a Shirrua, Locality 360182; b Paraguachon, Locality 430121; c La Tienda, Locality 290432; d Kabarauremana, Locality 430214 e Kaitamana, Locality 430118; f Shorotiju, Locality 430119; g Patajau Sur, Locality 430105; h Patajau North, Locality 430103; i Vertebrates, Locality 170533; j Yotojoro, Locality 430203; k Aiptiamana, 
Fig. 3 continued
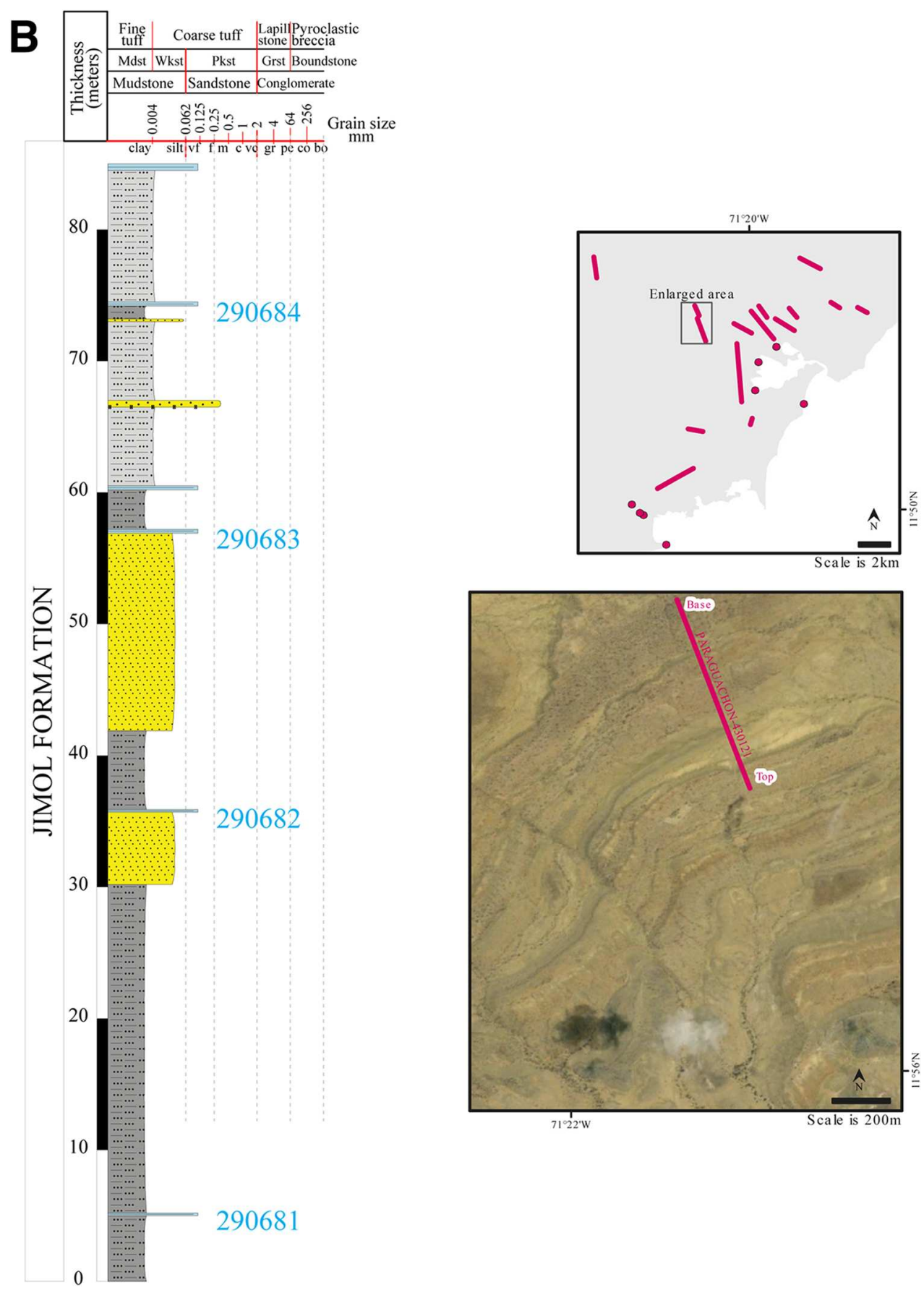

isotopic analyses (Online Resource 1). Lithological descriptions and classifications were done following Dunham (1962) nomenclature for carbonate rocks and Folk (1980) nomenclature for terrigenous rocks. A Jacob's staff was used to measure stratigraphic sections where feasible. GPS and geologic compass data, tied to satellite imagery, were used to measure cover intervals. We used SDAR software (Stratigraphic Data Analysis in R) to digitize stratigraphic data collected in the field. SDAR software is developed in the $\mathrm{R}$ language (R Development Core Team 2013) and combined with a MySQL database designed to store stratigraphic data, to graphically represent stratigraphic, sedimentological, and paleontological data (Ortiz et al. 2013).

The development of a chronostratigraphy was achieved through a combination of ${ }^{87} \mathrm{Sr} /{ }^{86} \mathrm{Sr}$ isotopic analyses and molluskan biostratigraphy. ${ }^{87} \mathrm{Sr} /{ }^{86} \mathrm{Sr}$ isotopic ratios can be measured in marine calcareous shells and marine calcareous sediment, and values can be compared with global ratios of ${ }^{87} \mathrm{Sr} /{ }^{86} \mathrm{Sr}$ through geologic time to estimate a 
Fig. 3 continued

C
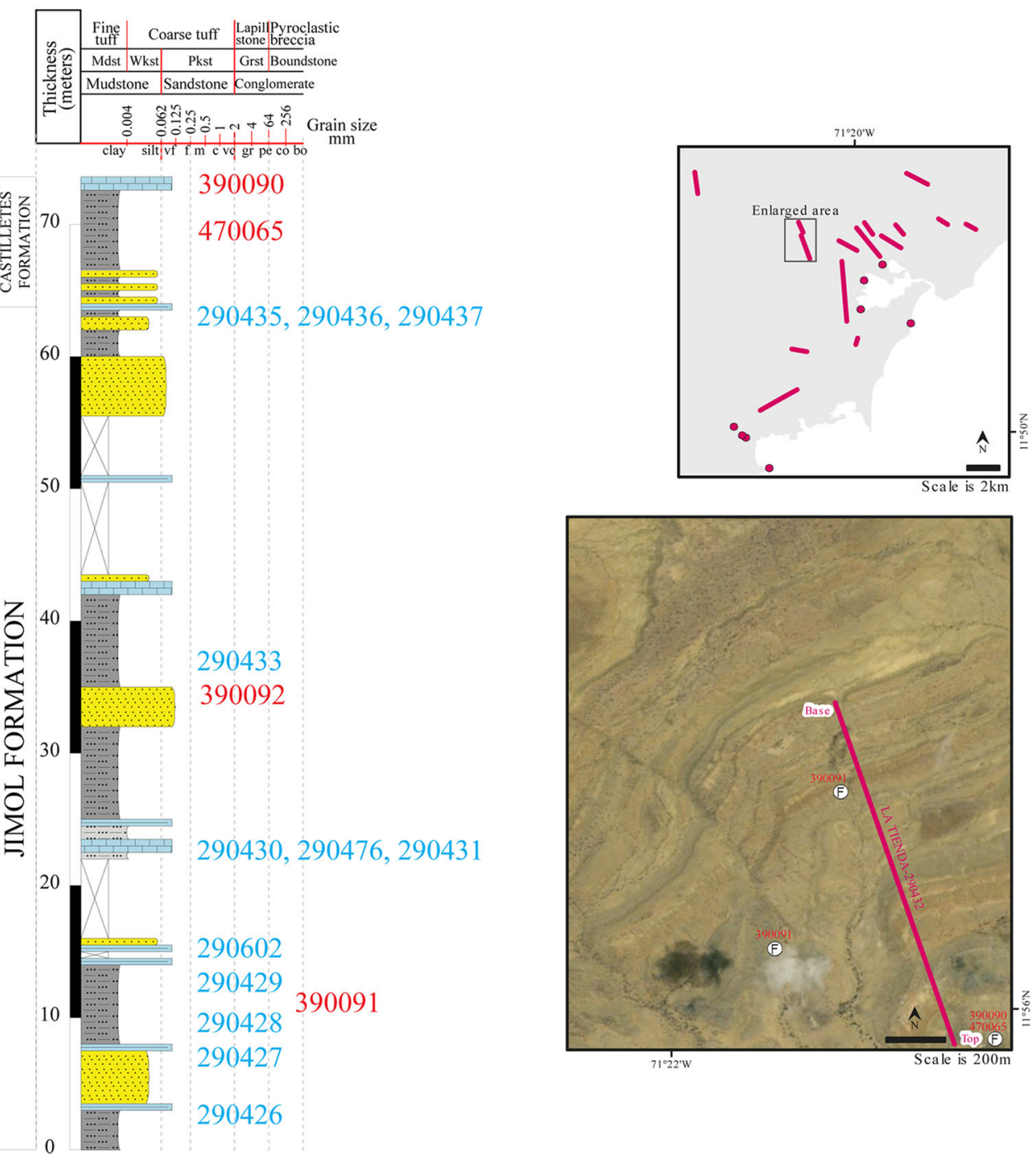

geologic age (Burke et al. 1982; McArthur 1994; Peterman et al. 1970; Wickman 1948). We sampled the thickest and most pristine calcareous shells in marine strata through the upper Jimol, Castilletes, and Ware Formations although we concentrated sampling in apparent intervals of geochronological interest. Following sampling and analytical protocols used in Kirby et al. (2007, 2008) we first ground off a portion of the surface layer of each shell specimen to reduce possible contamination, avoiding areas showing chalkiness or other signs of diagenetic alteration. Powdered samples of approximately $0.01-0.03 \mathrm{~g}$ were drilled from the interior of each shell using a hand-held Dremel tool. The powdered calcite samples were dissolved in $100 \mu \mathrm{l}$ of $3.5 \mathrm{~N} \mathrm{HNO}_{3}$ and then loaded onto cation exchange columns packed with strontium-selective crown ether resin (Eichrom Technologies, Inc.) to separate $\mathrm{Sr}$ from other ions (Pin and Bassin 1992). Sr isotope analyses were performed on a Micromass Sector 54 Thermal Ionization Mass Spectrometer equipped with seven Faraday collectors and one Daly detector in the Department of Geological Sciences at the University of Florida. Sr was loaded onto oxidized tungsten single filaments and run in triple collector dynamic mode. Data were acquired at a beam intensity of about $1.5 \mathrm{~V}$ for ${ }^{88} \mathrm{Sr}$, with corrections for instrumental discrimination made assuming ${ }^{86} \mathrm{Sr} /{ }^{88} \mathrm{Sr}=0.1194$. Errors in measured ${ }^{87} \mathrm{Sr} /{ }^{86} \mathrm{Sr}$ are better than $\pm 0.00002(2 \sigma)$, based on long-term reproducibility of NBS $987\left({ }^{87} \mathrm{Sr} /{ }^{86} \mathrm{Sr}=0.71024\right)$. Age estimates were determined using the Miocene and Pliocene portions of LookUp Table Version 4:08/03 (Howarth and McArthur 1997; 
Fig. 3 continued
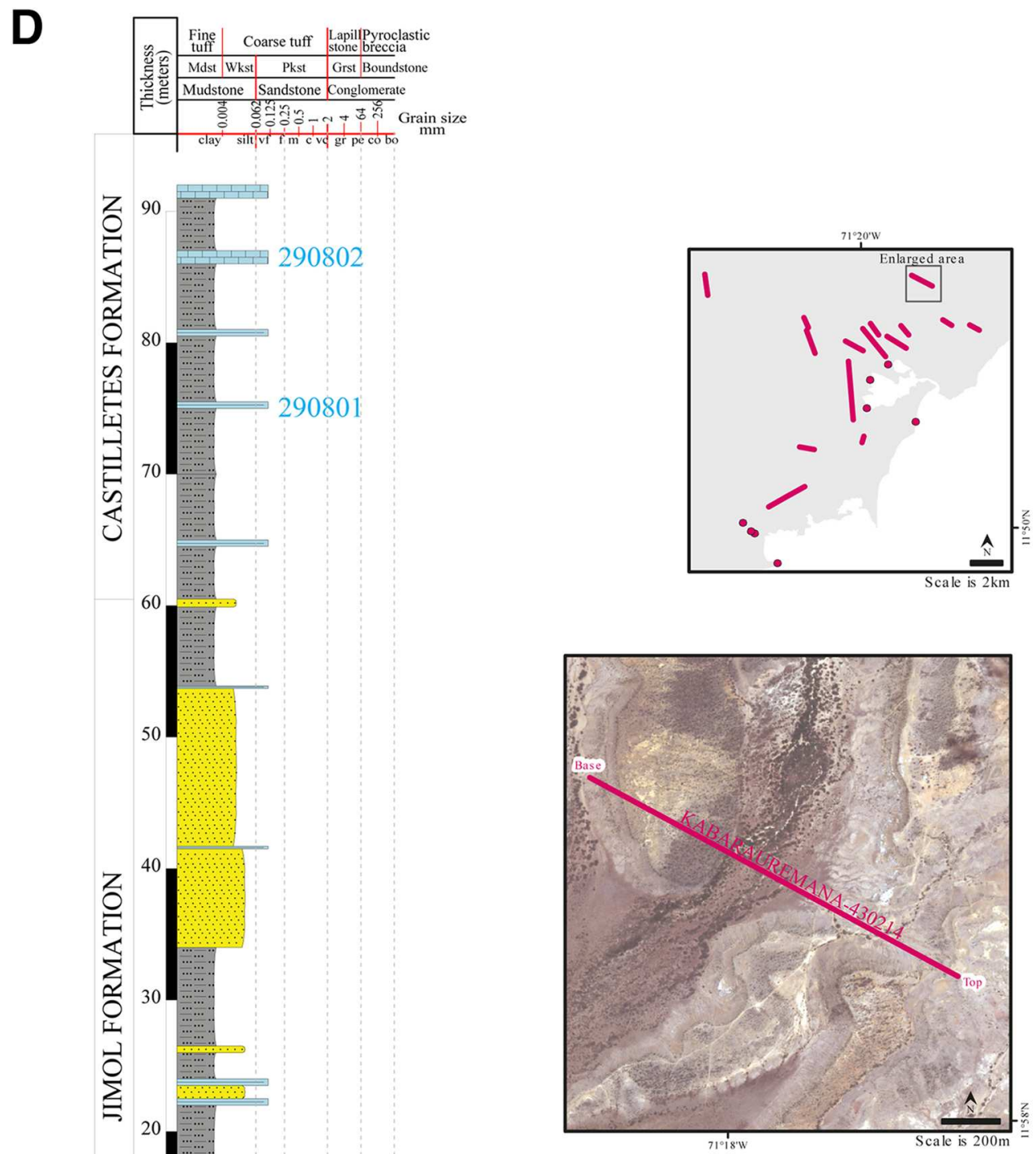

McArthur et al. 2001) associated with the strontium isotopic age.

We used six-digit identification numbers (IDs) to label field localities and stratigraphic sections. IDs correspond to consecutive numbers assigned in the field by the geologist. IDs for stratigraphic sections refer to the base point of each section. Most field localities are related to a single stratigraphic section, which determined their stratigraphic position. A single locality may include one or more samples, or field observations. Each individual specimen or rock collected has also a unique STRI-ID number together with the locality ID. All information on the stratigraphic sections, locality, and sample ID data can be accessed at the STRI PaleoDatabase (http://biogeodb.stri.si.edu/jaramillo2/ fossildb/).

\section{Lithostratigraphy}

Extensive stratigraphic fieldwork revealed a new boundary between the Jimol and Castilletes formations. In addition, an angular unconformity within the upper part of the 
Fig. 3 continued

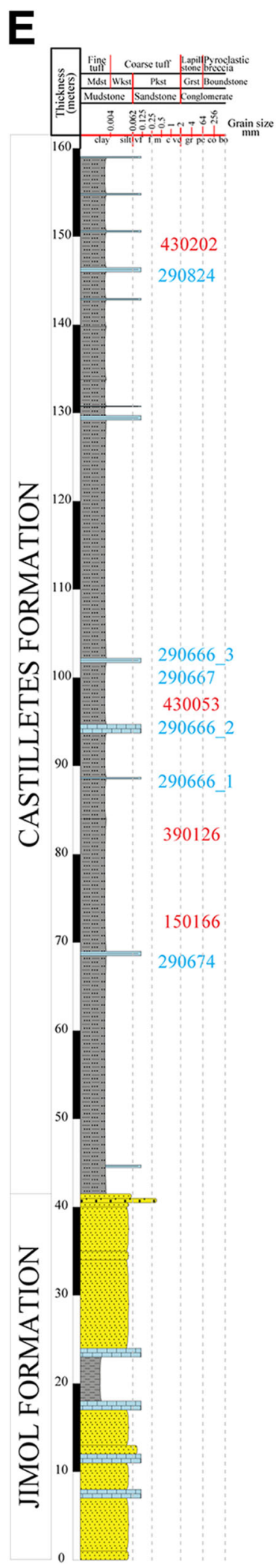

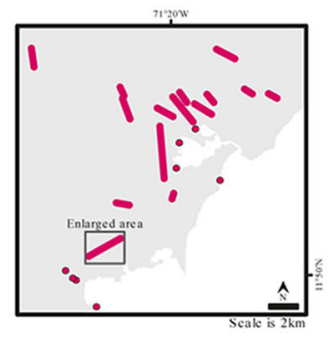

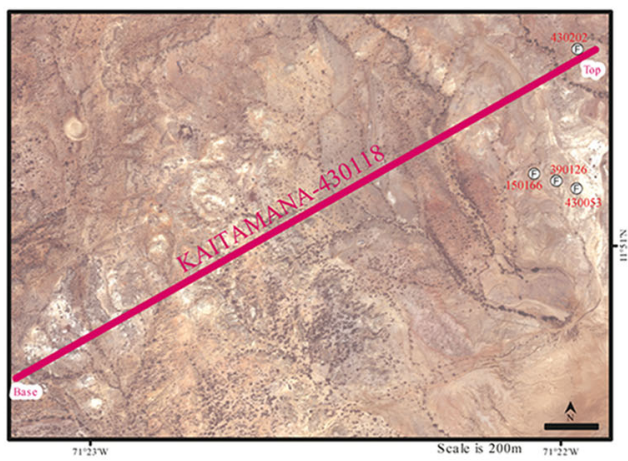


Fig. 3 continued

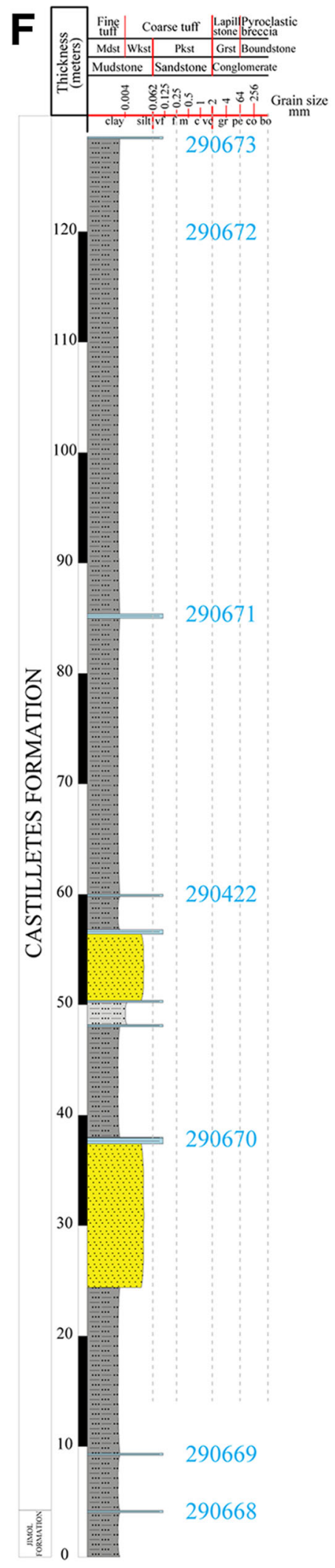

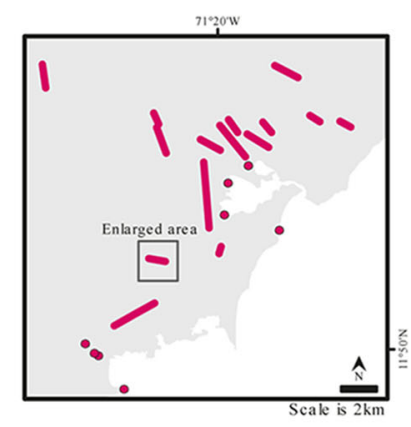

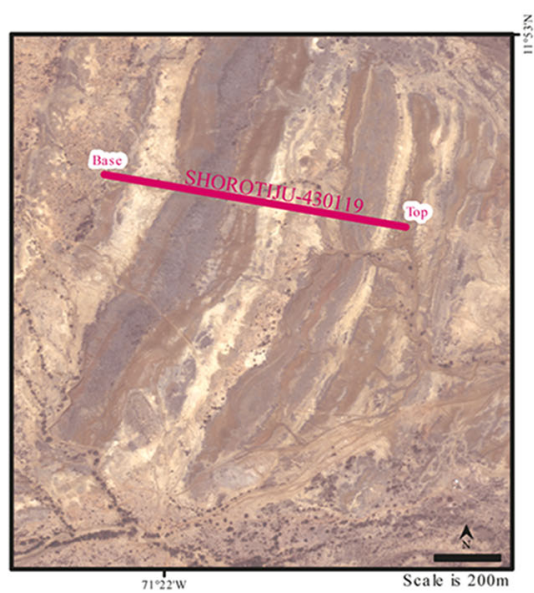


Fig. 3 continued
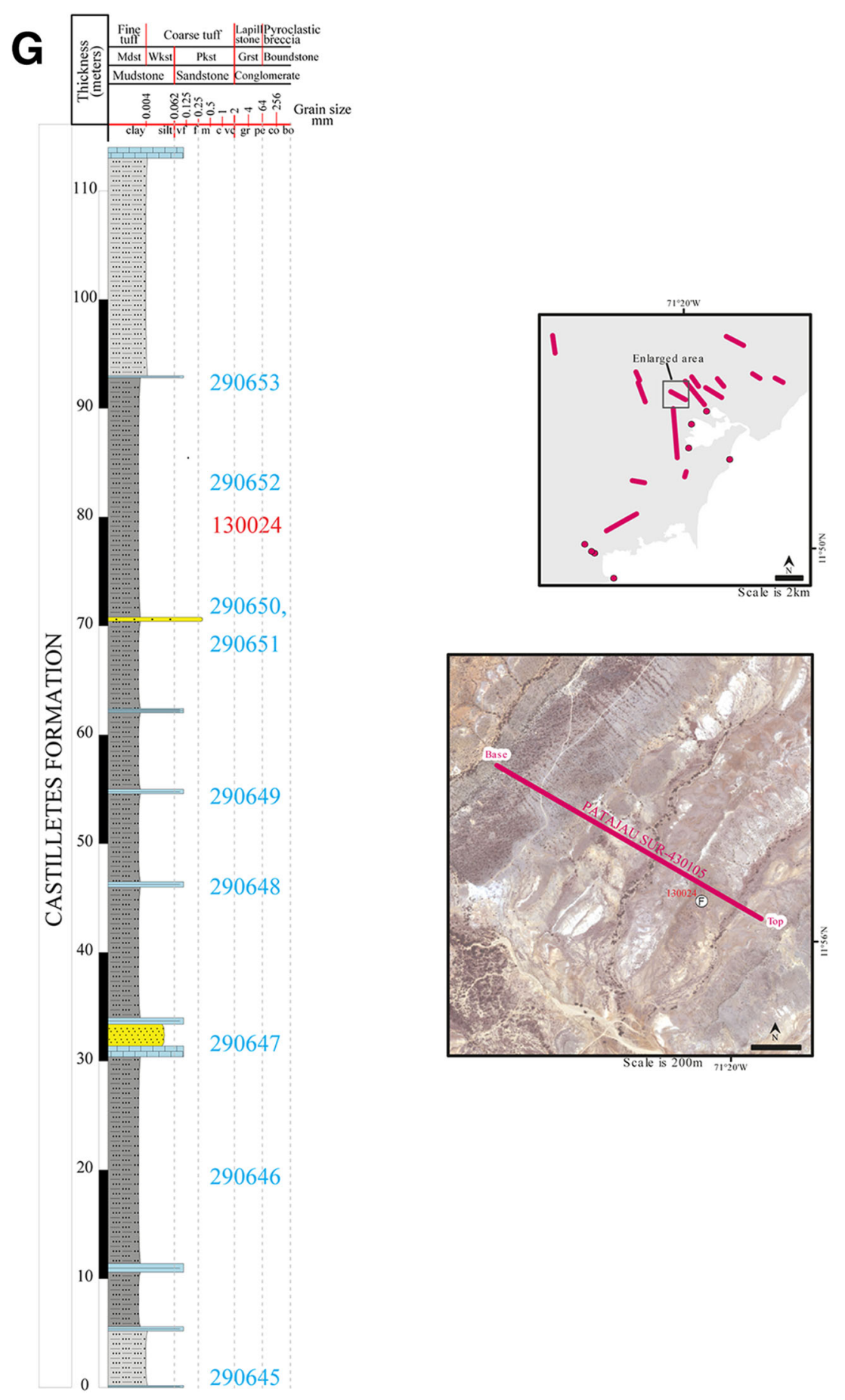

Castilletes Formation of Rollins (1965) was identified in the field. Major changes in faunal composition and the results of ${ }^{87} \mathrm{Sr} /{ }^{86} \mathrm{Sr}$ dating confirmed these observations and revealed a considerable gap in the geological record from ca. 14.5 Ma to ca. 3.5 Ma (Table 2). These results led us to define a new geological unit, the Ware Formation, which includes those strata above the unconformity, and to exclude the upper part of the Castilletes Formation sensu Rollins (1965) from our new definition of Castilletes. Furthermore, fieldwork revealed a number of impressive and distinctive fossil assemblages in each of the Jimol, Castilletes, and Ware formations.

We described 26 stratigraphic sections comprising the Jimol, Castilletes, and Ware Formations (Figs. 3, 4; 
Fig. 3 continued
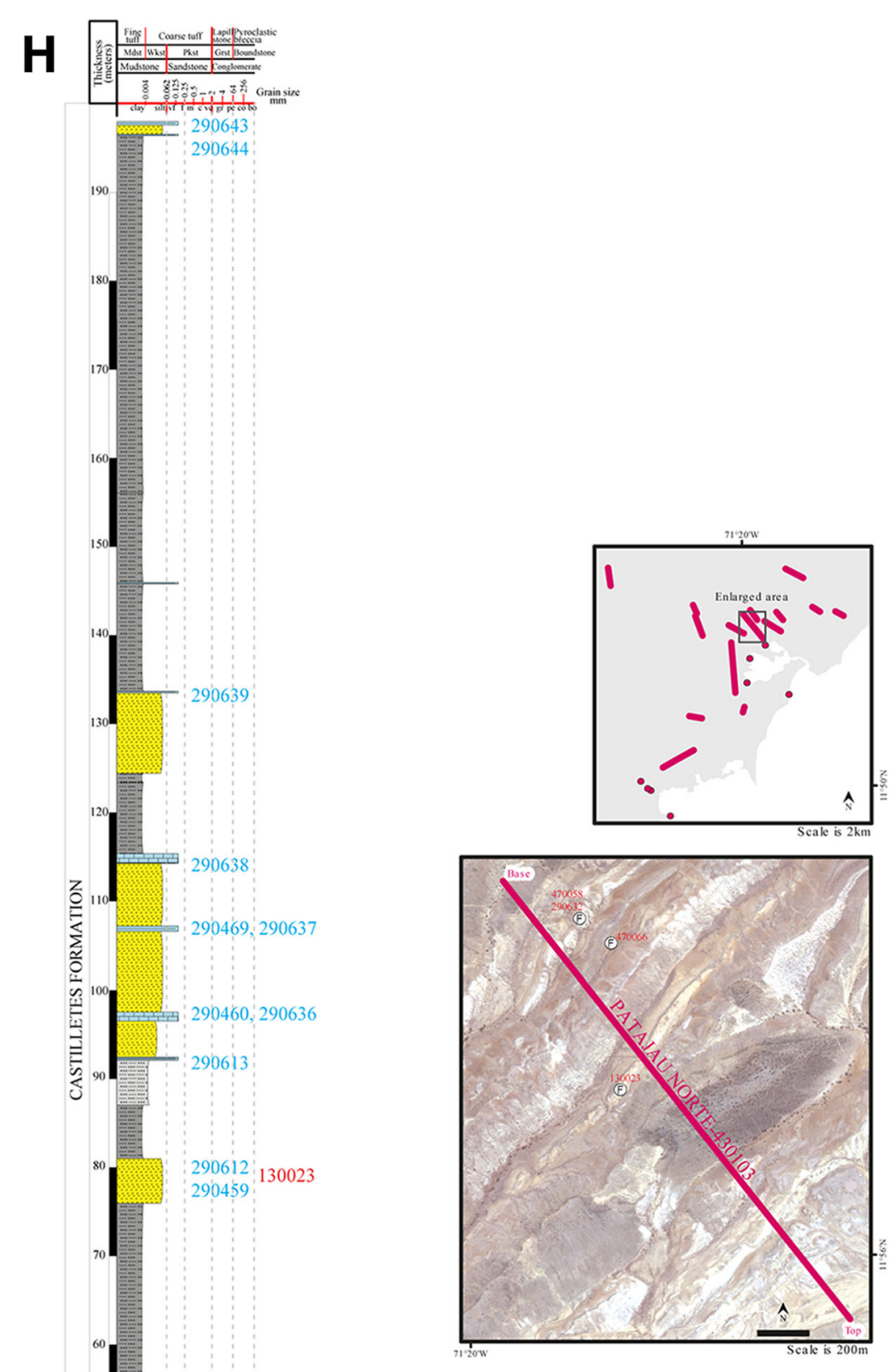
Fig. 3 continued

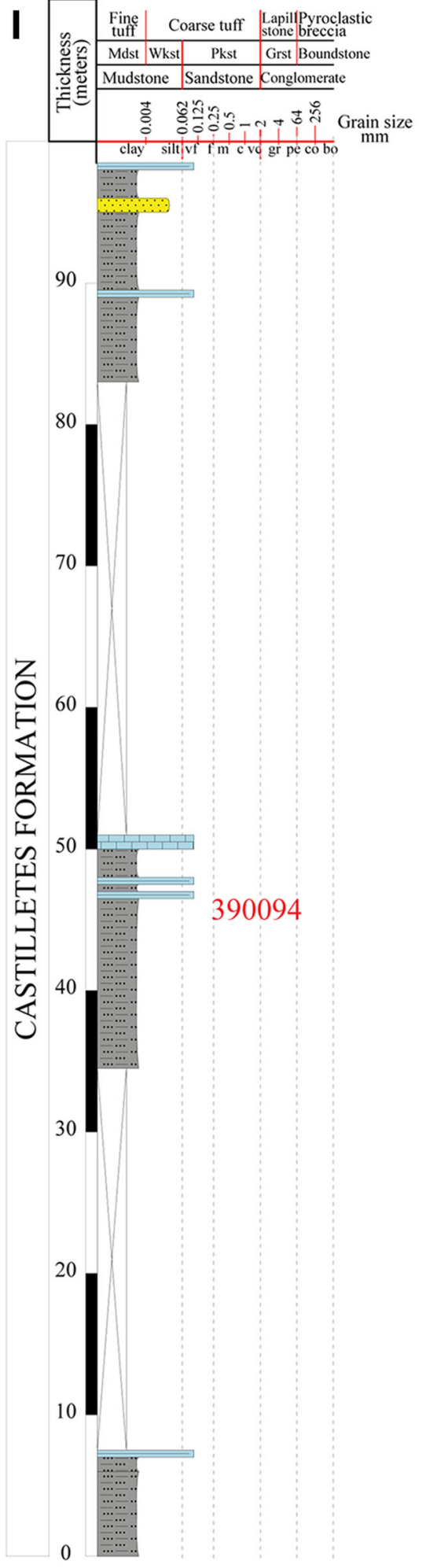

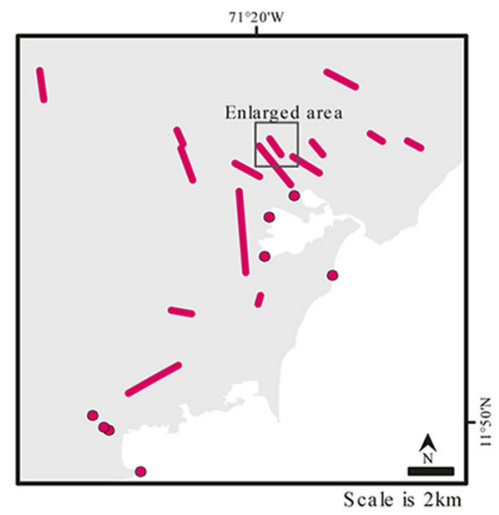

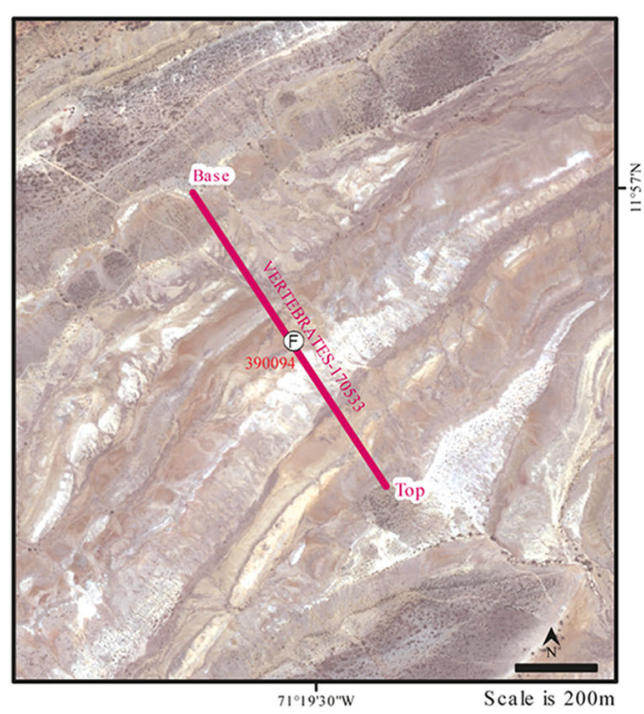


Fig. 3 continued

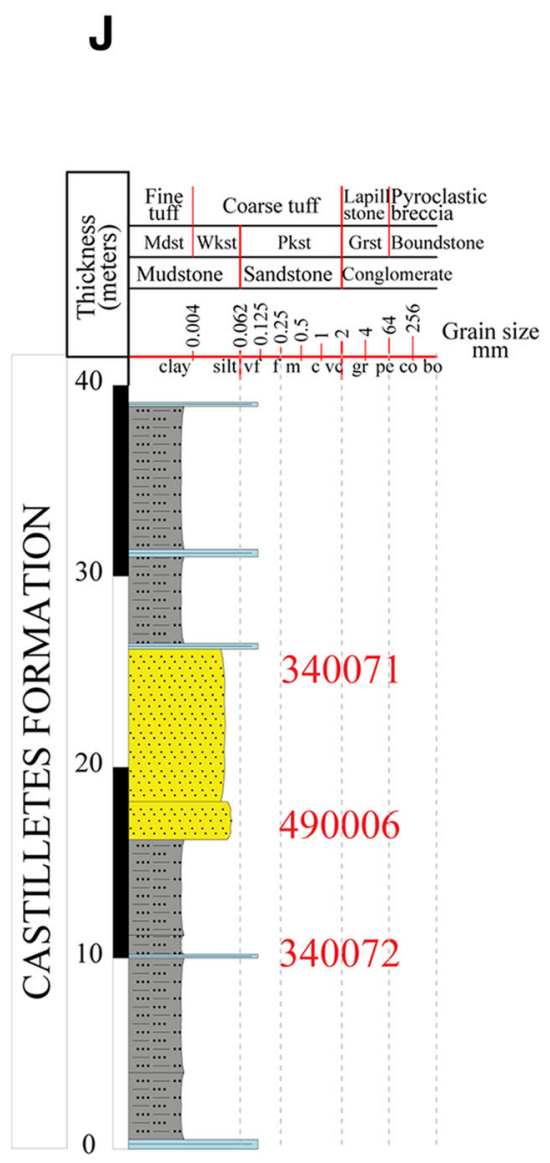

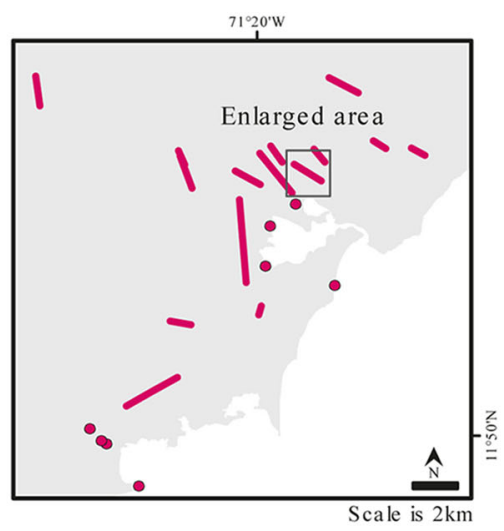

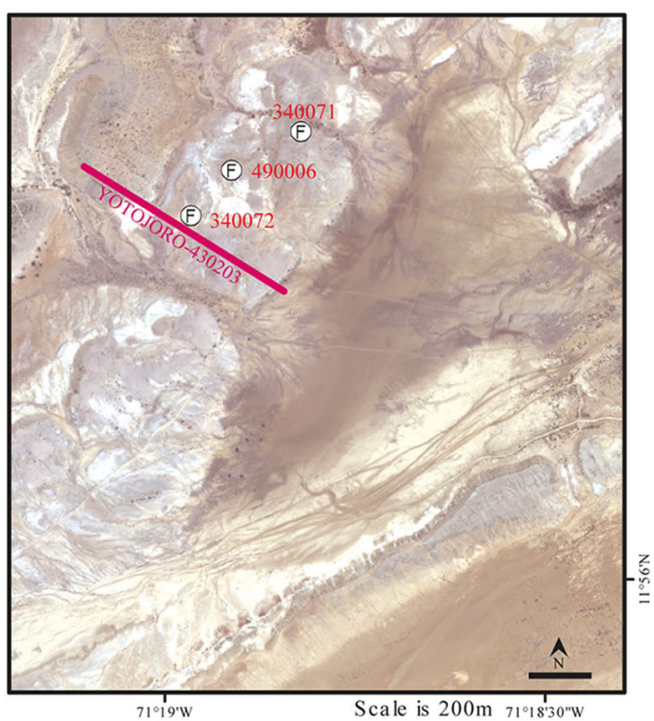

Table 3, Online Resources 1). Four sections define the new composite-lectostratotype of the Jimol Formation (La Tienda-290432, Shirrua-360182, Kaitama-430118, and Paraguachón-430121). Twenty-one sections of the Castilletes Formation were measured. Of those, sections including Patajau Norte-430103, Shavo-430200, Long-170514, Bahía Tucacas Sur-430117, and Topio Este-290825 constitute its new composite lectostratotype. Sections Patsua Sur-Este-430113 and Topio Oeste430170 contain the angular unconformity separating the Castilletes Formation of the proposed Ware Formation. We measured four stratigraphic sections constituting the Ware Formation, including its type section (Estación de Policia-430052).

\section{Jimol formation}

Here, we present a new definition for the Jimol Formation. Depositional environment interpretation will be presented in the following section.
Name Renz (1960) named the formation after Cerro Jimol located in the SE portion of the Jarara Range.

Lectostratotype Paraguachón Valley, between the Arroyo Shirrua and the north boundary of the Patajau Valley. Base of the composite section at $11.97790^{\circ} \mathrm{N}, 71.42234^{\circ} \mathrm{W}$, and top at $11.93286^{\circ} \mathrm{N}, 71.35949^{\circ} \mathrm{W}$ (Figs. 4 and 5).

Description The Jimol Formation is composed of gray calcareous lithic sandstone and lithic sandstone, yellowish gray fossiliferous wackstone to packstone, and gray to brown siltstones and mudstone. At the base, $50 \mathrm{~cm}$ to $1 \mathrm{~m}$ thick beds of coarse calcareous lithic sandstone and lithic sandstone, with ripples, cross and planar bedding, and fossiliferous wackestone to packstone dominate the sequence. There are occasional $\sim 5 \mathrm{~m}$ thick beds of siltstone and mudstone in this part of the sequence. At the top mudstone, fine-grained calcareous lithic sandstone, and lithic sandstone, 5-20 m thick beds dominate the sequence interbedded with $50 \mathrm{~cm}-2 \mathrm{~m}$ thick beds of fine- to medium-grained calcareous sandstone, and fossiliferous wackestone to packstone (Fig. 5). 
Fig. 3 continued
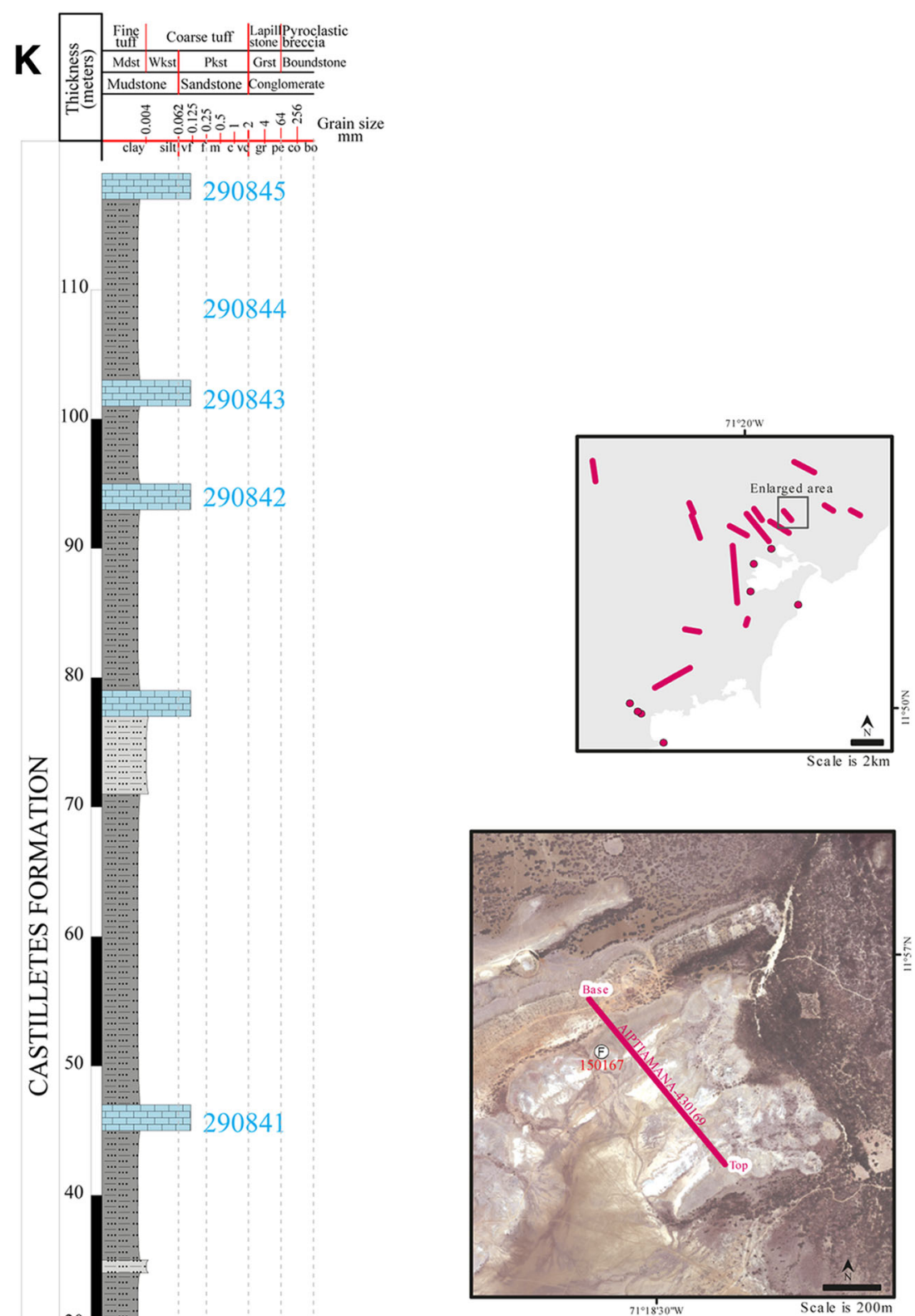

290837

290839

290840

150167

20

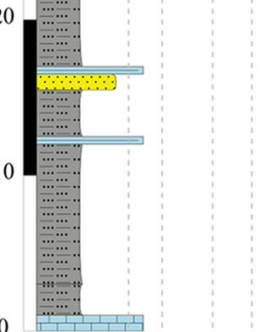


Fig. 3 continued
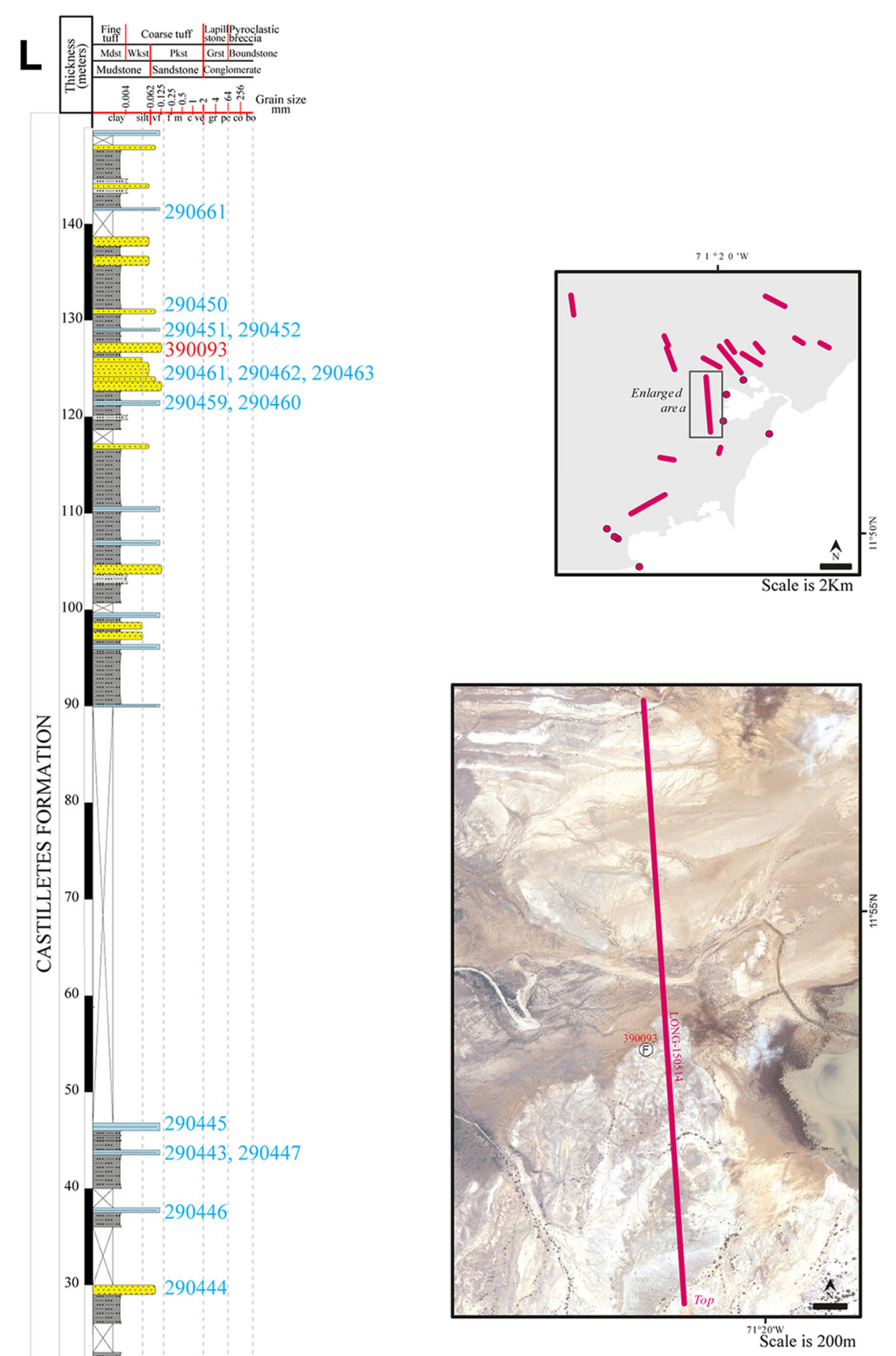
Fig. 3 continued

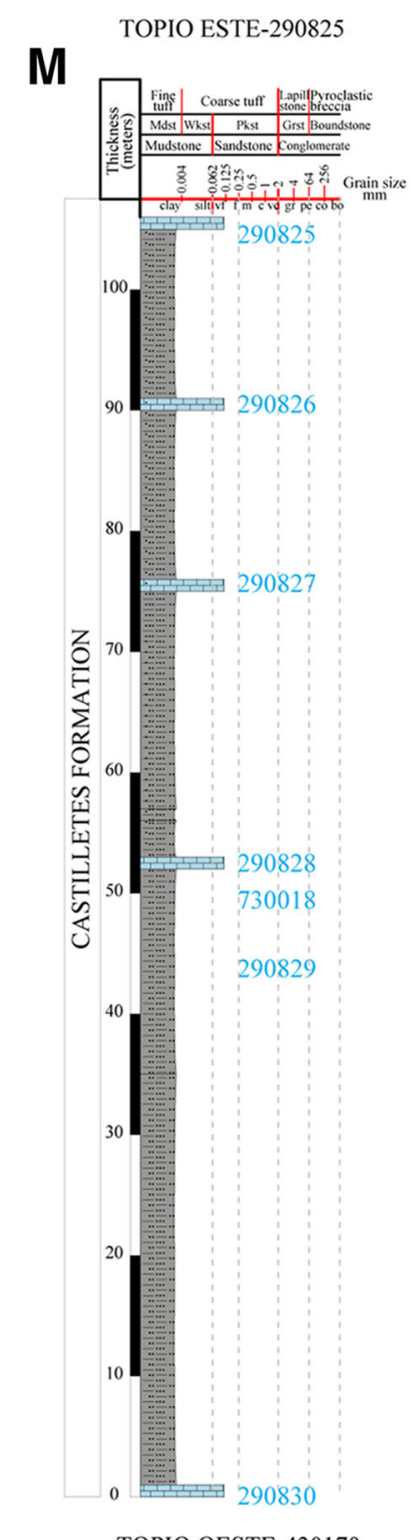

TOPIO OESTE-430170

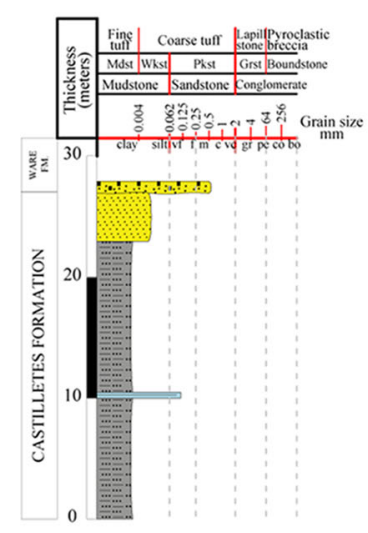

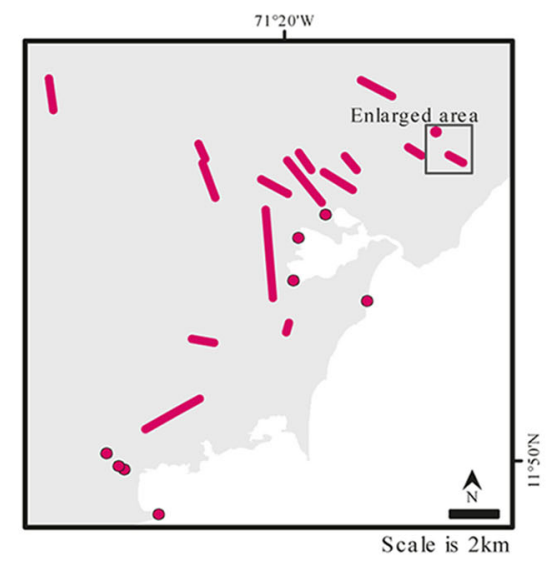

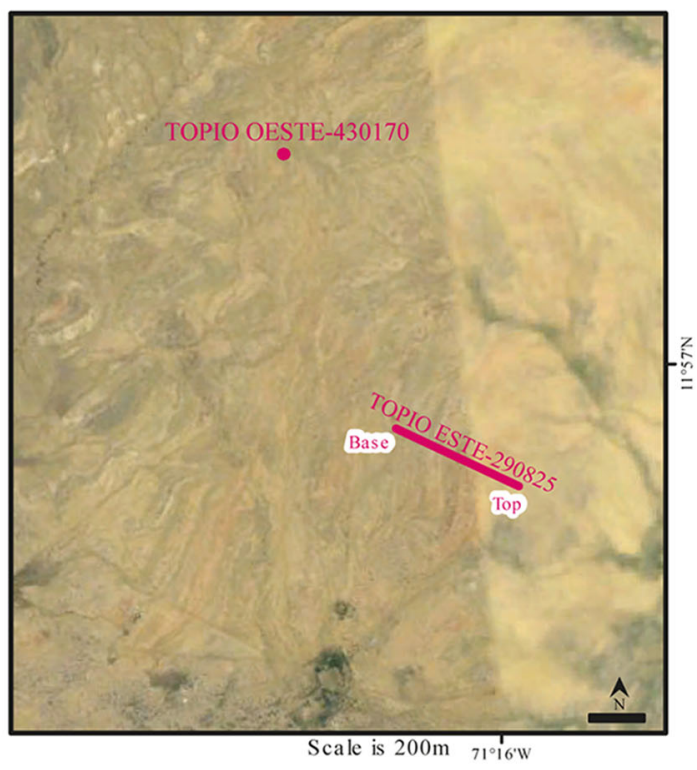


Fig. 3 continued
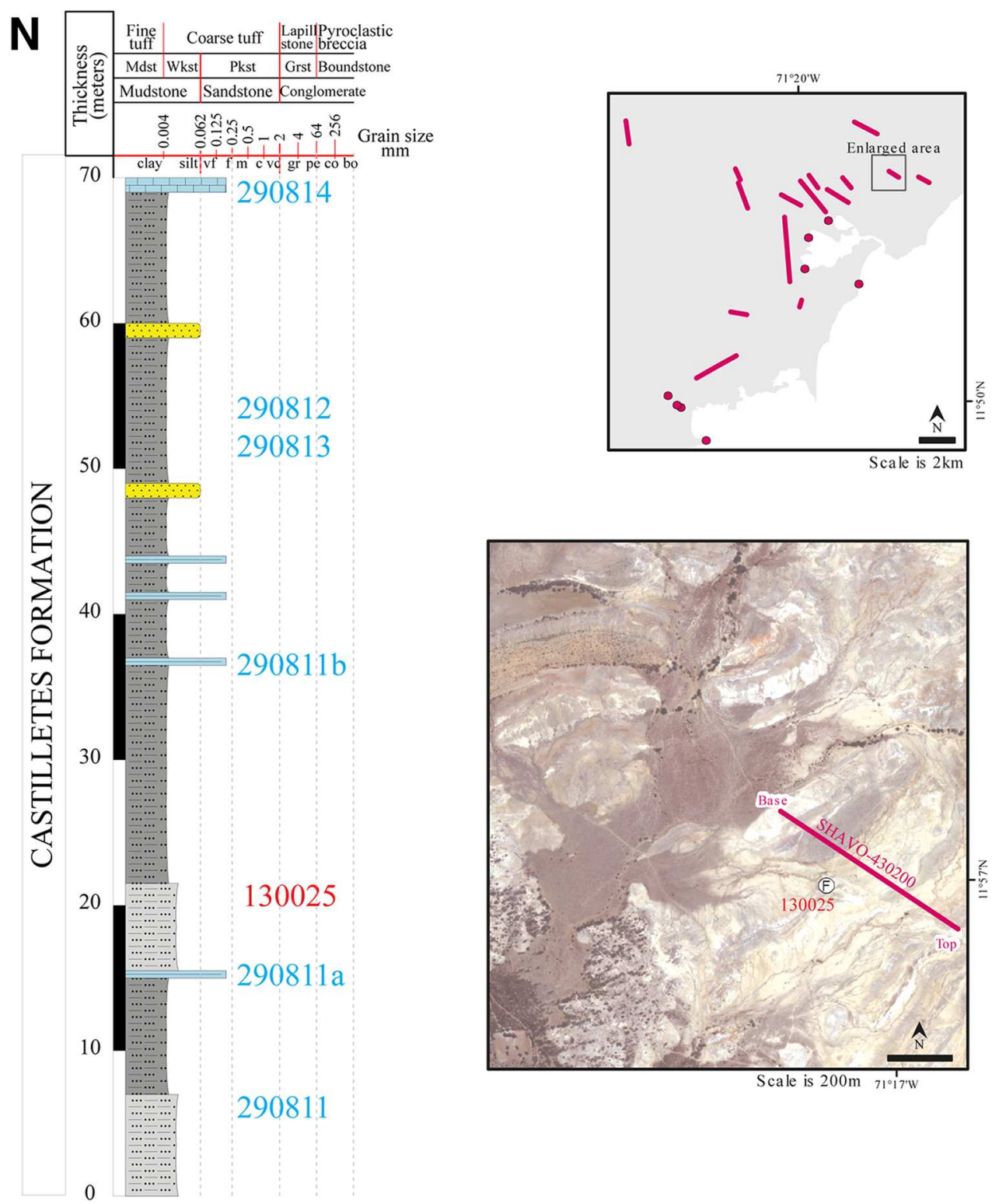

Lower and upper boundaries The lower boundary of the Jimol Formation was defined by Rollins (1965) as the sandy limestone that makes a prominent scarp over the clays of the Uitpa Formation. We retain this lower boundary in our redefinition of the Jimol Formation, as it is a prominent feature easily seen in the field. We position the new upper boundary at a hardground surface at the top of a fossiliferous wackestone that crops out in the northern limit of Patajau Valley. This surface not only represents a distinct change in facies within the stratigraphic succession from relatively coarse and well-cemented lithologies to those that are fine-grained and unconsolidated of the overlying Castilletes Formation, but also results in a change in topographic expression that can enable the contact to be followed laterally across much of Cocinetas Basin. This facial change is conspicuous and can be noted by the shift from the sandy facies of the Jimol Formation dominated by medium to coarse calcareous lithic sandstone and occasional recessive levels composed of mudstone and siltstone, to the muddy facies of the Castilletes Formation dominated by thick recessive levels of mudstone and siltstone with occasional beds of medium to coarse lithic to 

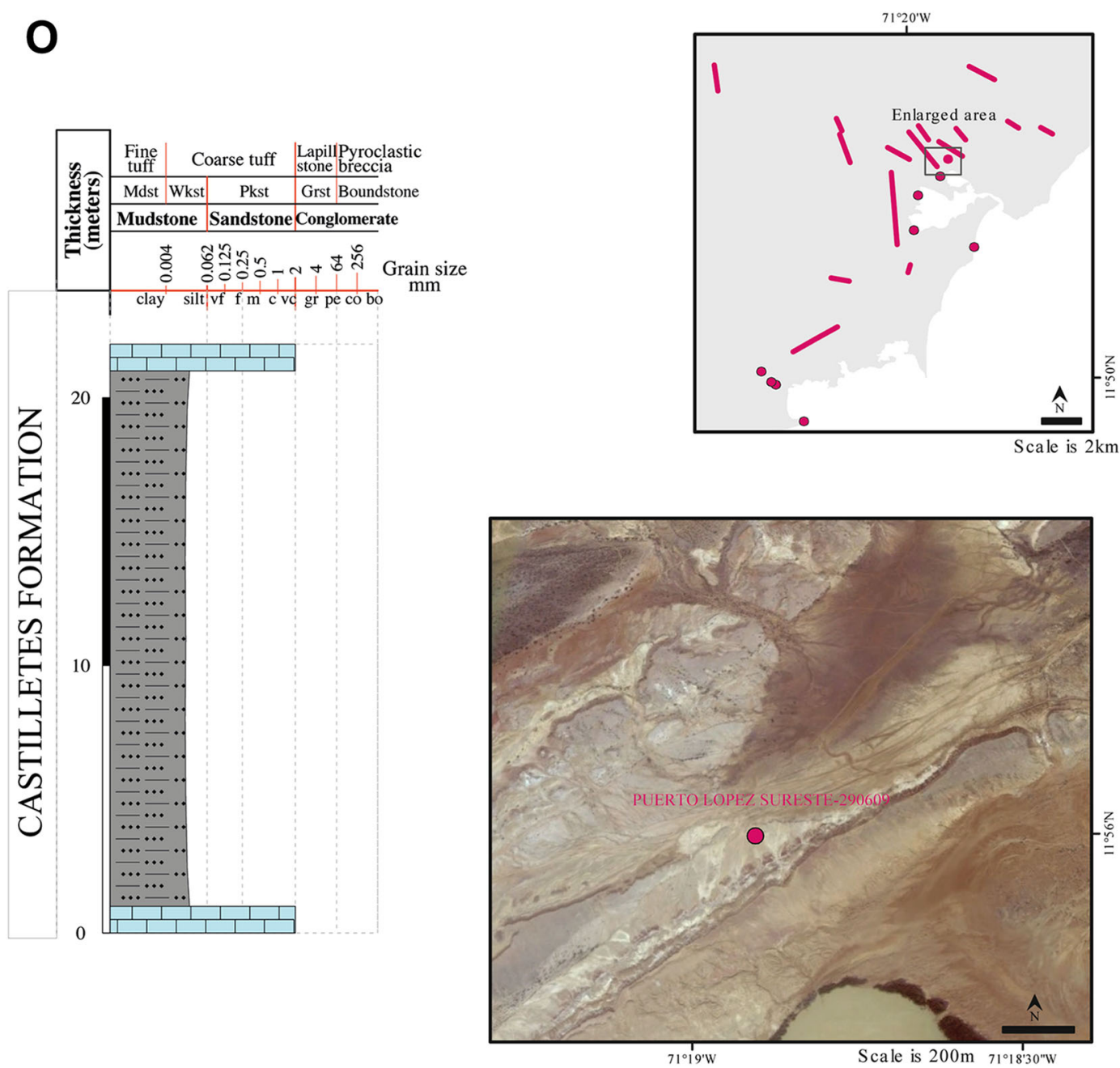

Fig. 3 continued

quartz sandstone, and fossiliferous wackstone to packstone. The hardground surface itself has been observed in multiple transects across this contact. Both boundaries are conformable.

Thickness and regional extent A total thickness of 203 meters was measured in the stratotype, although this should be considered a conservative estimate given the difficulties in measuring poorly exposed strata in the middle portion of the formation. The Jimol Formation forms a NE-SW trended stripe along the central part of Cocinetas Basin, from the Patsua Valley in the south up to Rio Topio in the north (Figs. 5 and 6).

Invertebrate palaeontology Dominant taxa of the Jimol Formation include Turritella, Anadara (Cunearca), Crassostrea, Dallocardia, and Pitar. Other characteristic taxa include Potamides, Neverita, Glossaulax, Orthaulax,
Melongena, Turbinella, Conus, Tucetona, Glyptoactis, Eucrassatella, Clementia, and Macrocallista. Around 103 'species' of mollusks (51 bivalves, 51 gastropods, and 1 scaphopod) have been identified from the formation (see Hendy et al. (2015), in this issue, for a detailed description of this assemblage).

Vertebrate Palaeontology: Two specimens of Crocodilia have been found in two different localities (Tables 4, 5; Online Resource 2). Otoliths of bony fishes and teeth of sharks (Squaliformes, Lamniformes, and Carcharhiniformes) and rays (Myliobatiformes) also have been found.

Age The invertebrate fauna of the Jimol Formation shares high similarity with the Cantaure Formation (latest Early Miocene) of Venezuela (Jung 1965) and the Culebra Formation (Early Miocene) of Panama (Woodring 1957). 
Fig. 3 continued

P Bahía Tucacas Sur-430117

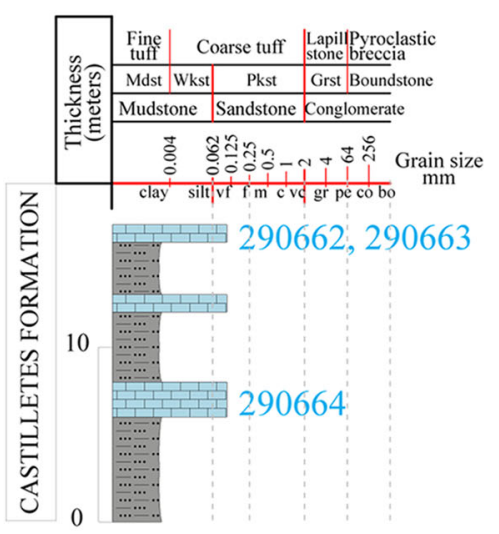

Bahía Tucacas Medio-430116

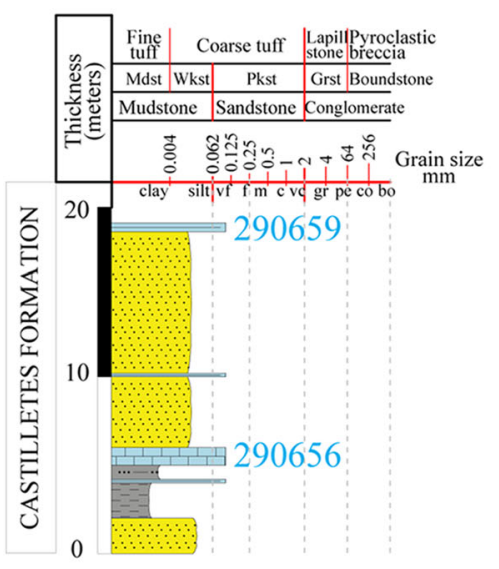

\section{Bahia Tucacas Norte-430115}
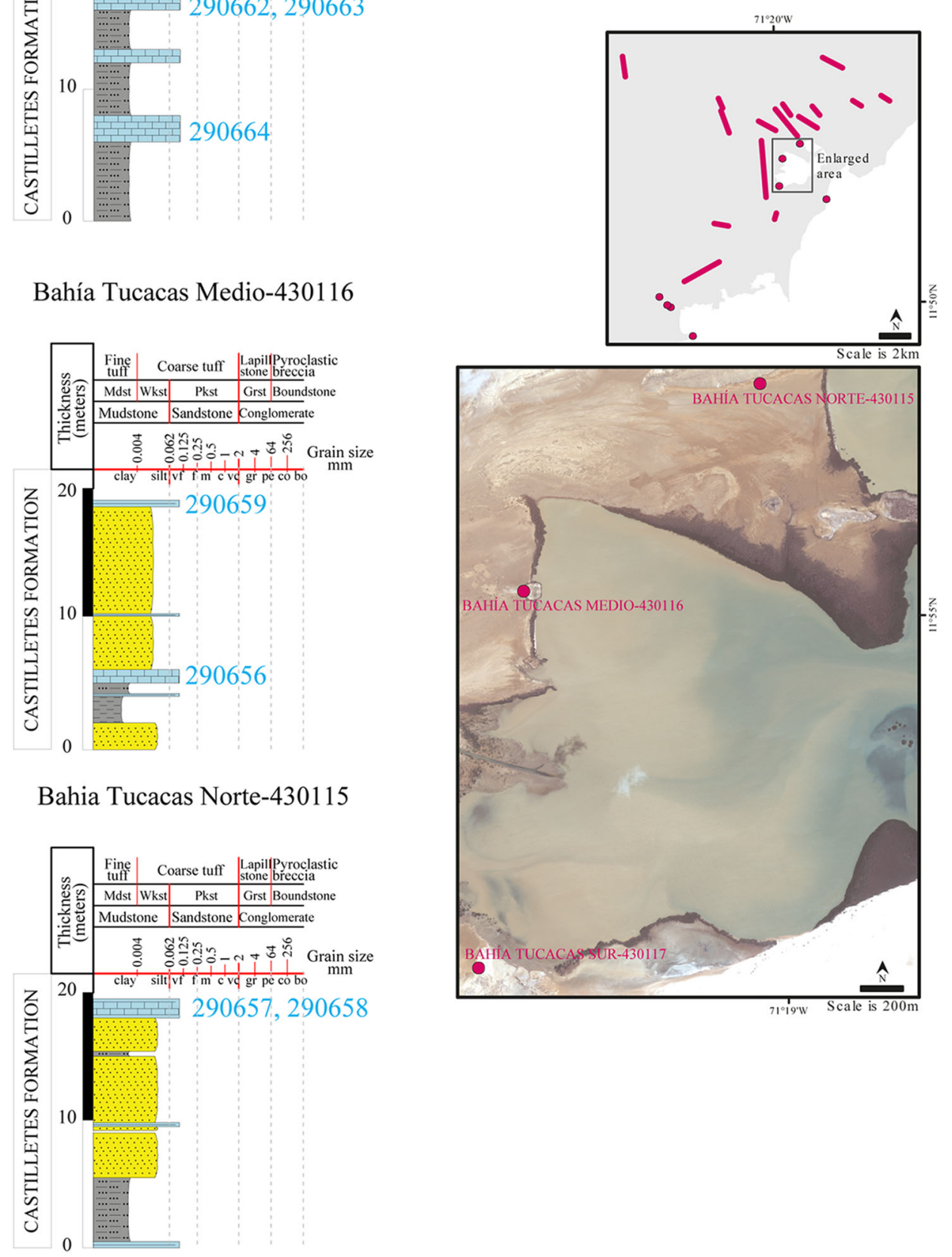

Most notable among mollusks are frequent specimens of Orthaulax, a taxon that is widespread in the Caribbean during the Early Miocene and earliest Middle Miocene
(Vokes and Vokes 1968). Other marine invertebrate taxa identified from the formation are regarded as indicative of the latest Early Miocene (e.g., "Paraleptopecten" 
Fig. 3 continued

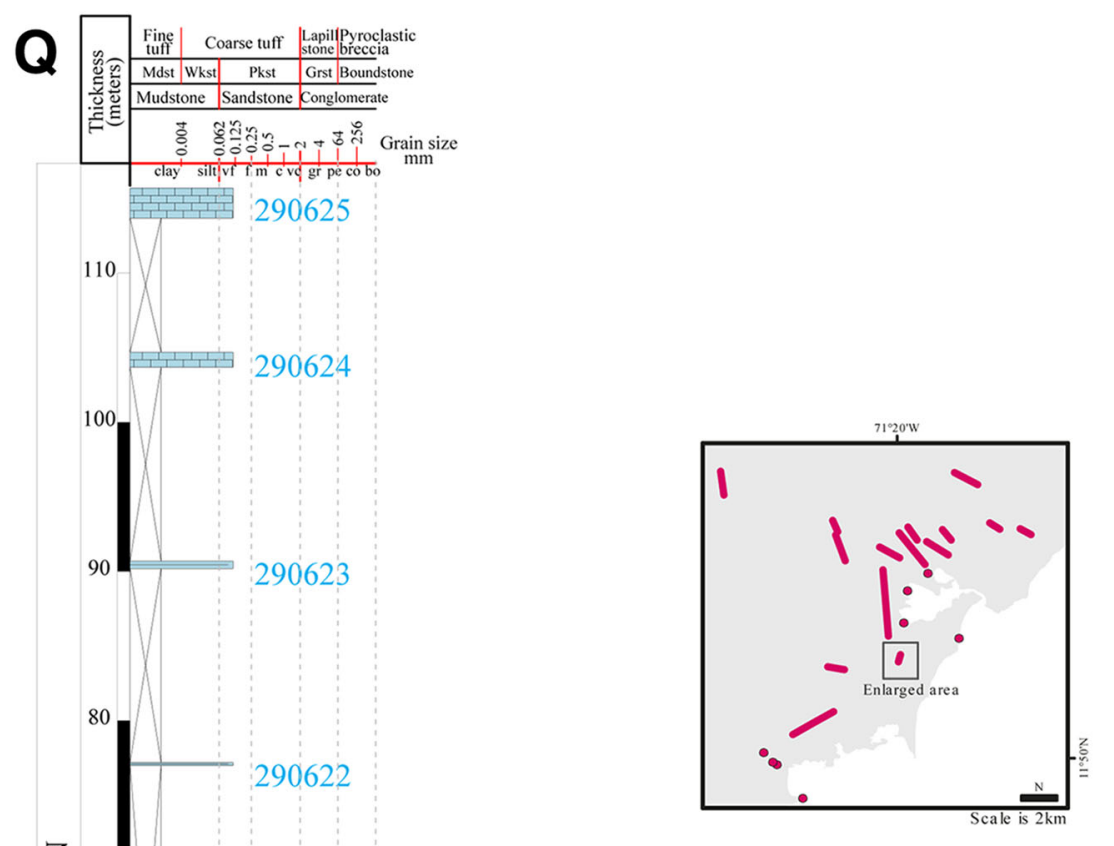

Z

50

40

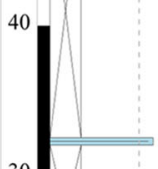

30

290620

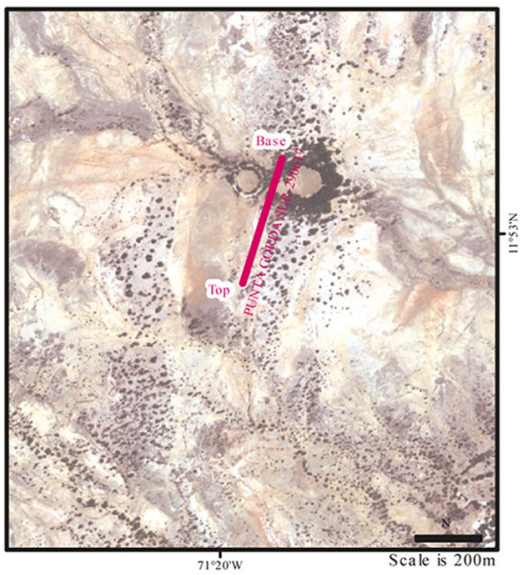

quirosensis, Cyclinella venezuelana, and Conus cf. chiporatios, a mean age of $17.3 \mathrm{Ma}$ (range of $16.89 \pm 0.12 \mathrm{Ma}-$ lanus) or Middle Miocene (e.g., Modulus tamenensis), or $17.51 \pm 0.11$ month year) is calculated for beds northwest of the village of Paraguachón at the top of the formation are similar to Middle-Late Miocene forms (e.g., Lindapecten cf. buchivacoanus). On the basis of ${ }^{87} \mathrm{Sr} /{ }^{86} \mathrm{Sr}$ (Table 2).

$$
\text { A late Early Miocene }
$$

(Burdigalian 


\section{R Padsua Este-430112}
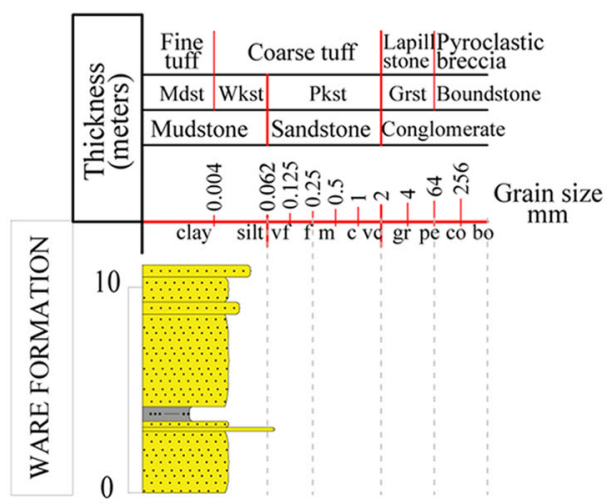

\section{Padsua Sur-430113}

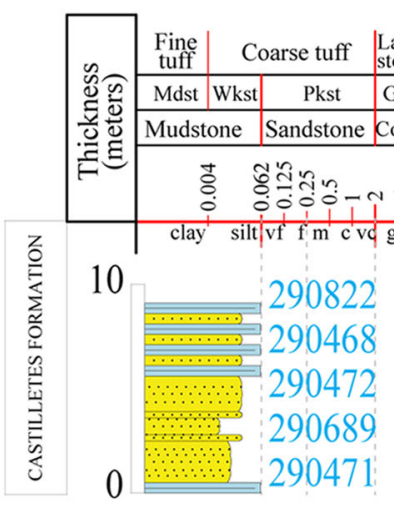

\section{Padsua Norte-430205}

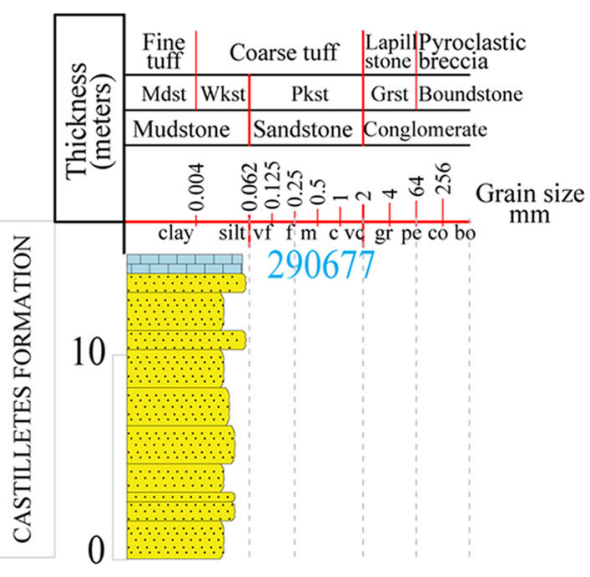

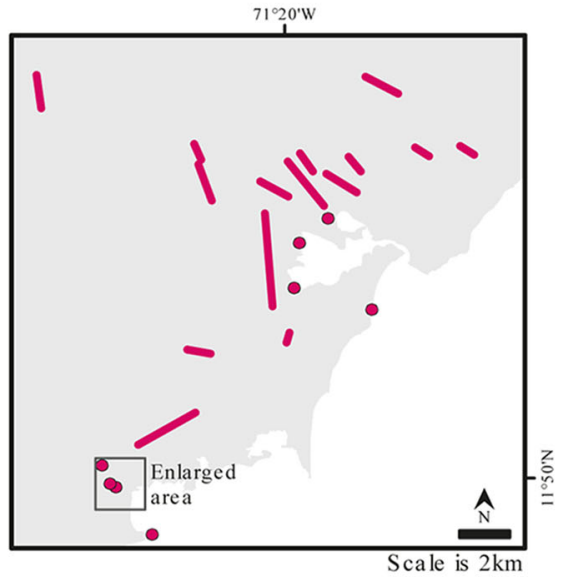

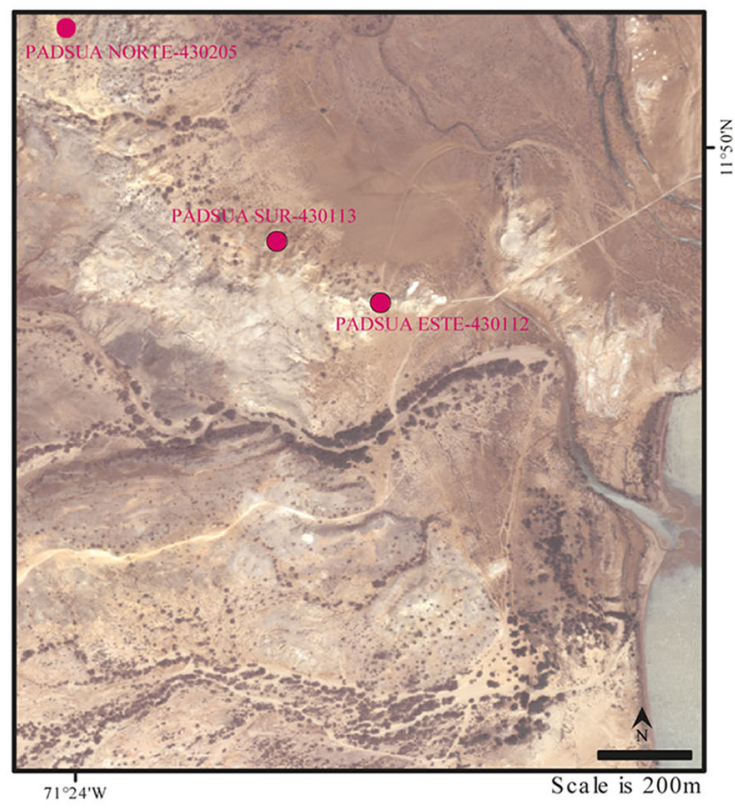

Fig. 3 continued 

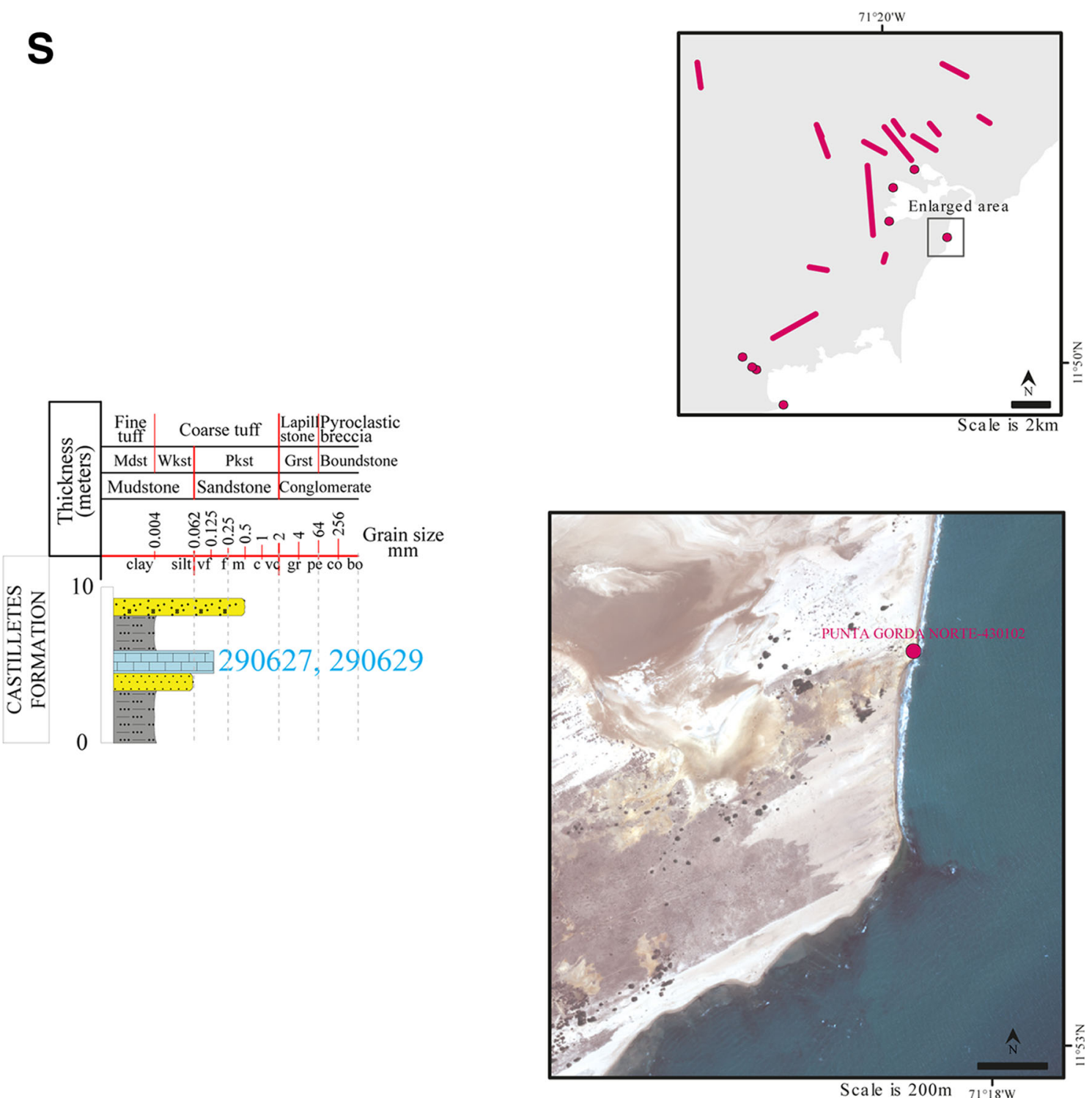

Fig. 3 continued

17.9-16.7 Ma) age is, therefore, assigned to the Jimol Formation on the basis of macroinvertebrate biostratigraphy and ${ }^{87} \mathrm{Sr} /{ }^{86} \mathrm{Sr}$ isotope chronostratigraphy (see also Hendy et al. (2015) in this issue).

Environment of deposition The Jimol Formation was deposited in a shallow marine environment, inner shelf depth $(<50 \mathrm{~m})$.

Correlations This unit is correlated with the upper Agua Clara Formation, lower Cerro Pelao Formation of Falcon Basin in Venezuela (Fig. 2). The formation is also correlative with the Cantaure Formation (ca. 18-17 Ma) of the Paraguaná Peninsula in Venezuela (Díaz de Gamero 1974; Rey 1996).

\section{Castilletes formation}

Here, we present a new definition for the Jimol Formation. Depositional environment interpretation will be presented in the following section.

Name The formation is named after the town of Castilletes, located in the Guajira Peninsula (Rollins 1965).

Lectostratotype The area between Patajau Valley and Makaraipao village in the central Cocinetas Basin (Figs. 4 and 7). Coordinates for the base and top of the composite stratigraphic section are $11.946800^{\circ} \mathrm{N}$ and $71.3321833^{\circ} \mathrm{W}$, and $11.94896^{\circ} \mathrm{N}$ and $71.27136^{\circ} \mathrm{W}$, respectively. 

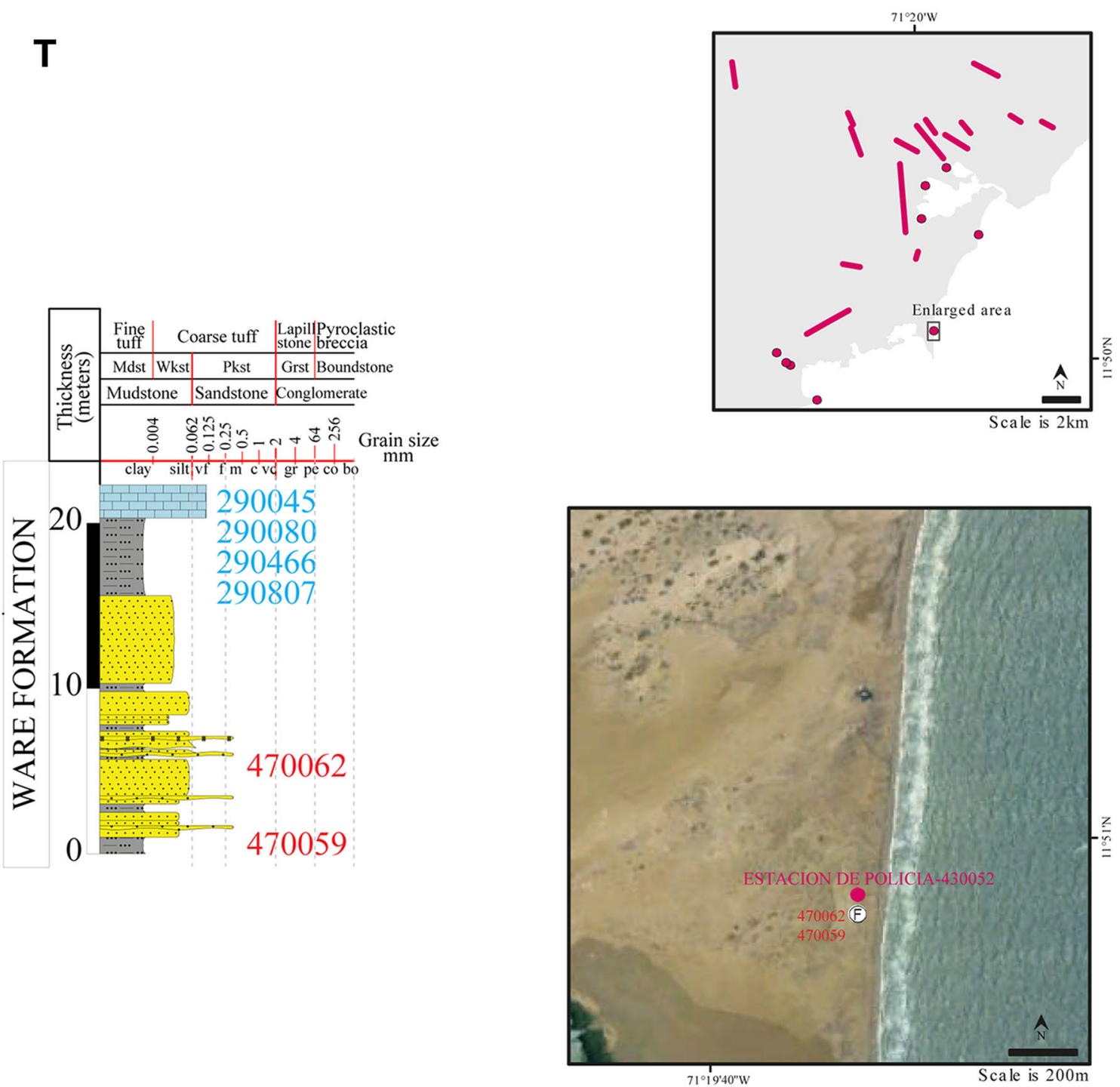

Fig. 3 continued

Description The formation is composed of gray massive mudstone, fossiliferous mudstone and siltstone, fossiliferous wackestone to packstone, and medium-grained to conglomeratic fossiliferous lithic to quartz sandstone. Thick successions of mudstone $(\sim 50 \mathrm{~m})$ dominate the unit and form long valleys. Thin beds of biosparite and sandstone $(50 \mathrm{~cm}-2 \mathrm{~m})$ are interbedded and form laterally extensive ridges. Sandstone often present planar and crossbedded stratification. Sandy and silty facies increase toward the top of the formation, forming prominent hills. Fossiliferous horizons are common within the unit, with marine invertebrate fossils occurring in a broad range of facies (calcareous, sandy, silty, and muddy sediments), whereas terrestrial vertebrates tend to be restricted to muddy sediments and are often associated with freshwater invertebrate fossils. Sandy facies toward the top of the formation are also rich in vertebrate fossils (Figs. 7, 8).

Lower and upper boundaries The lower boundary of the Castilletes Formation is defined by a hardground surface that overlies a distinctive fossiliferous wackestone cropping out along the northern edge of the Patajau Valley. This surface can be observed along strike in several parts of the Cocinetas Basin. The upper boundary is an angular unconformable contact with the overlying Ware Formation (Fig. 9). This contact frequently is eroded or not exposed, cropping out only at a few sites when erosional remnants of the Ware Formation are preserved.

Thickness and regional extent A total thickness of $440 \mathrm{~m}$ was measured in the lectostratotype. The Castilletes Formation crops out along the eastern margin of the Cocinetas 

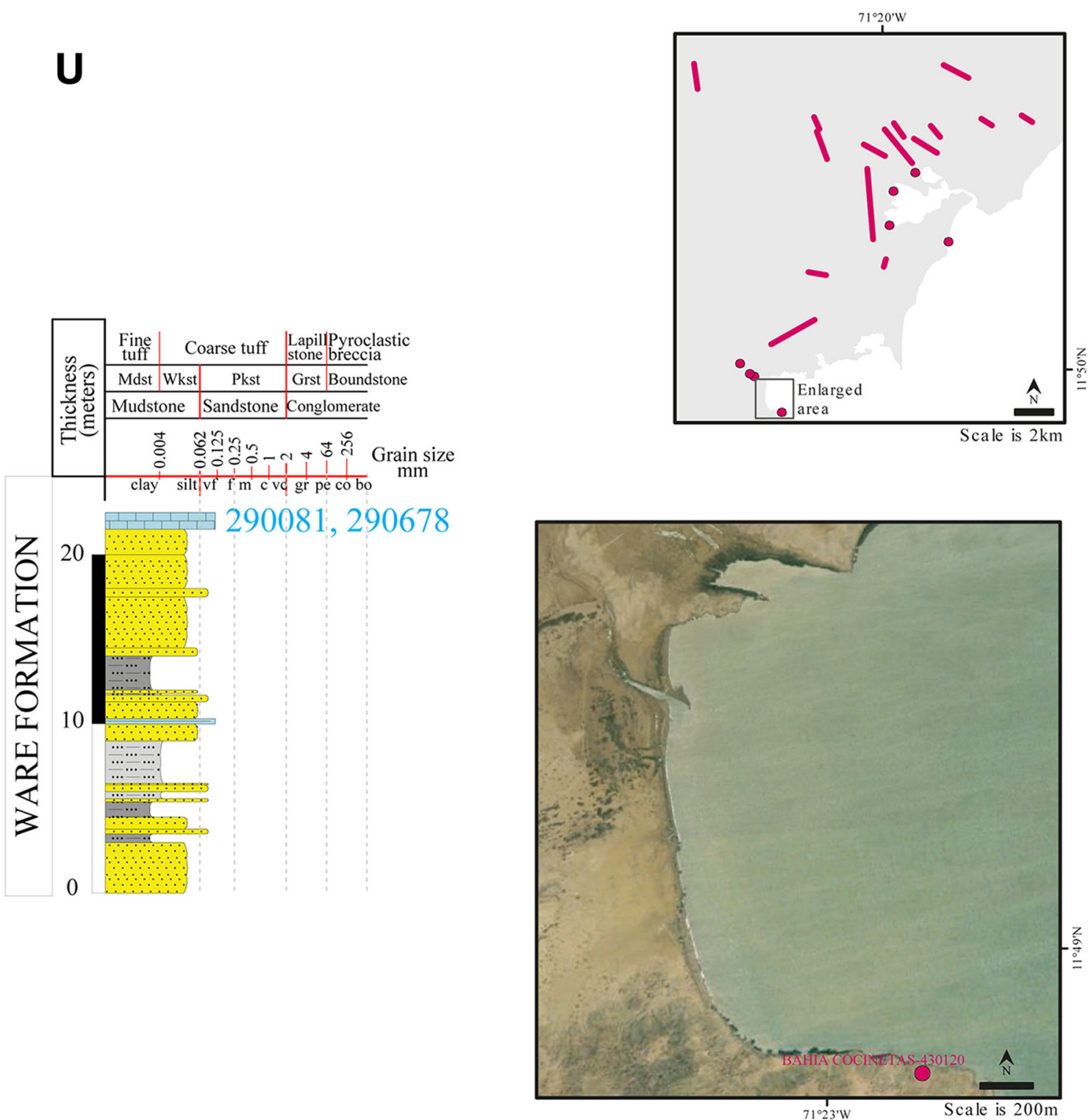

\section{Legend:}

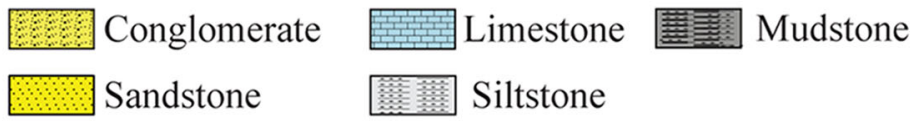

390126 Vertebrate locality

Stratigraphic section
290612 Invertebrate locality

(B) Fossiliferous locality

Fig. 3 continued

Basin, but correlative strata may occur farther north and south of the presently mapped area (Figs. 6 and 7).

Invertebrate palaeontology Dominant taxa of the Castilletes Formation include Potamides, Turritella, Anadara (Cunearca), and Pitar. Other frequently occurring 'genera' include Neverita (Glossaulax), Polinices, Melongena, Architectonica, Conus, Tucetona, Mytilus, Dallocardia, and Caryocorbula. A total of 149 'species' of mollusks ( 82 gastropods, 66 bivalves, and 1 scaphopod), 3 echinoderms, and 4 arthropods have been identified from 
Table 2 Strontium isotope data and age estimates from Cocinetas Basin, Colombia

\begin{tabular}{|c|c|c|c|c|c|c|c|}
\hline Unit & Section & Height (m) & Sample & Taxon & ${ }^{87} \mathrm{Sr} /{ }^{86} \mathrm{Sr}$ & Age $(\mathrm{Ma})^{\mathrm{a}}$ & $\overline{\text { Range }(\mathrm{Ma})^{\mathrm{a}}}$ \\
\hline Jimol & 290432 & 35 & 17068 & Anadara guajiraensis & 0.7086413 & 17.33 & $16.96-17.65$ \\
\hline Jimol & 290432 & 35 & 17068 & Anadara guajiraensis & 0.7086331 & 17.45 & $17.10-17.75$ \\
\hline Jimol & 290432 & 66 & 16882 & Turritella matarucana & 0.7086293 & 17.51 & $17.16-17.80$ \\
\hline Jimol & 290432 & 66 & 16882 & Turritella matarucana & 0.7086679 & 16.89 & $16.48-17.27$ \\
\hline Castilletes & 430103 & 104 & 17049 & Crassostrea sp. & 0.7087012 & 16.31 & $15.93-16.71$ \\
\hline Castilletes & 430103 & 104 & 17049 & Anadara guajiraensis & 0.708706 & 16.22 & $15.85-16.62$ \\
\hline Castilletes & 430103 & 104 & 17073 & Crassostrea sp. & 0.7086964 & 16.33 & $16.01-16.80$ \\
\hline Castilletes & 430103 & 104 & 17073 & Phacoides sp. & 0.7087145 & 16.07 & $15.71-16.46$ \\
\hline Castilletes & 170514 & 98 & 16918 & Anadara guajiraensis & 0.708774 & 15.14 & $14.50-15.51$ \\
\hline Castilletes & 170514 & 98 & 16918 & Anadara guajiraensis & 0.708766 & 15.29 & $14.79-15.64$ \\
\hline Castilletes & 170514 & 98 & 16918 & Anadara guajiraensis & 0.708759 & 15.39 & $14.97-15.75$ \\
\hline Castilletes & 170514 & 98 & 16918 & Anadara guajiraensis & 0.708767 & 15.27 & $14.76-15.62$ \\
\hline Castilletes & 170514 & 99 & 16885 & Glyptoactis paraguana & 0.708756 & 15.43 & $15.04-15.79$ \\
\hline Ware & 430052 & 21 & 10347 & Crassostrea virginica & 0.7091014 & 1.57 & $1.22-2.24$ \\
\hline Ware & 430052 & 21 & 10347 & Crassostrea virginica & 0.7090591 & 3.28 & $2.12-4.99$ \\
\hline Ware & 430052 & 21 & 10347 & Plicatula gibbosa & 0.7090639 & 2.78 & $1.93-4.82$ \\
\hline Ware & 430052 & 21 & 10347 & Euvola codercola & 0.7090584 & 3.4 & $2.15-5.03$ \\
\hline Ware & 430120 & 22 & 16880 & Argopecten sp. & 0.7090104 & 5.71 & $5.09-6.10$ \\
\hline Ware & 430120 & 22 & 16880 & Plicatula gibbosa & 0.709058 & 3.4 & $2.15-5.03$ \\
\hline
\end{tabular}

${ }^{a}$ Ages from look-up tables in McArthur et al. (2001)

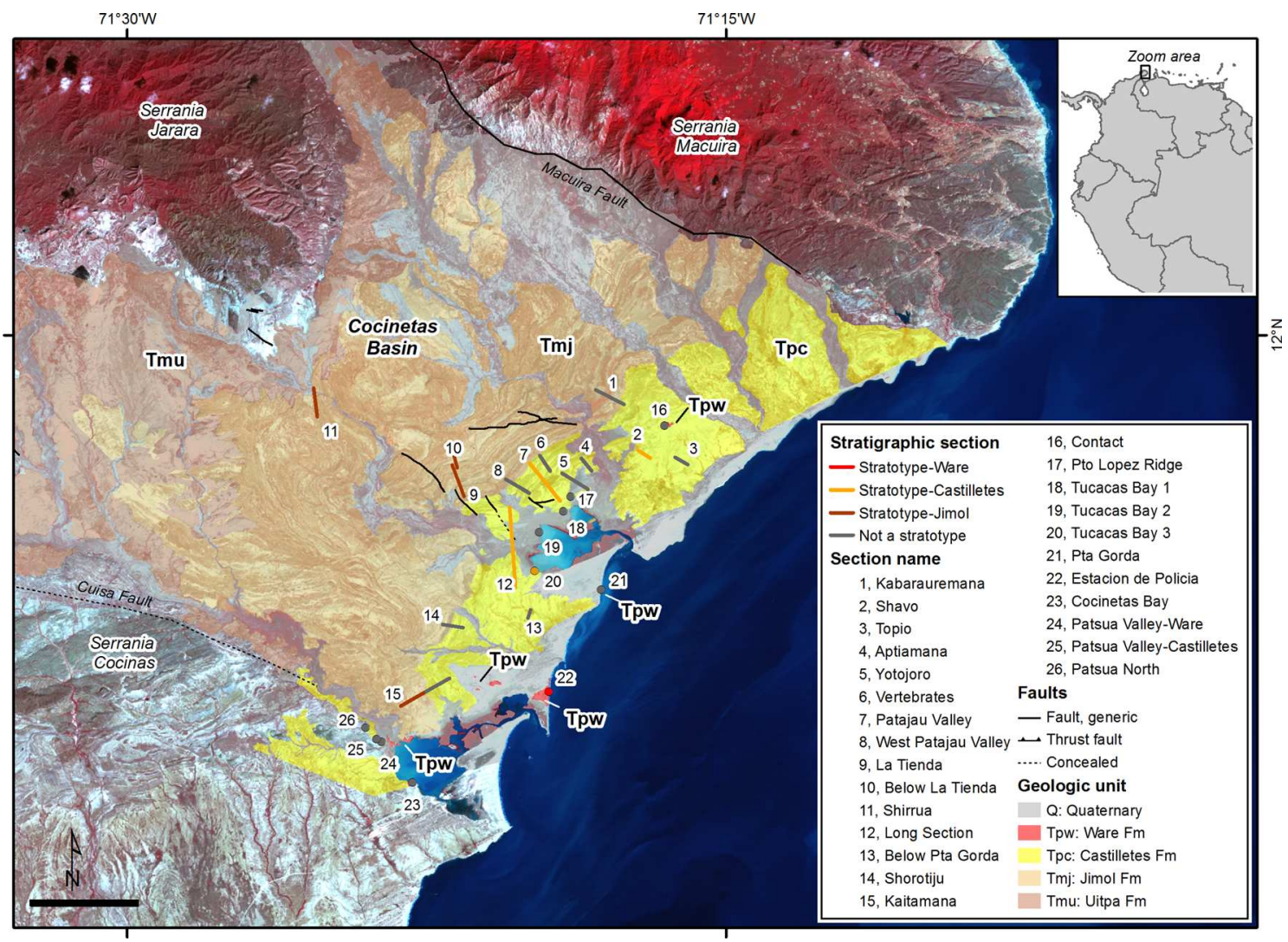

Fig. 4 Location of stratigraphic sections and stratotypes. Image from Landsat 8 OLI-TIRS sensor (January 10, 2014, RGB 432). Geologic units are shown in transparent colors. Scale bar is $5 \mathrm{~km}$ 
Table 3 Stratigraphic sections measured and described in the Cocinetas Basin

\begin{tabular}{|c|c|c|c|c|c|c|c|}
\hline Name & Locality ID & Start point Lat & Start point Long & End point Lat & End point Long & Units & $\begin{array}{l}\text { Stratigraphic } \\
\text { thickness }(\mathrm{m})\end{array}$ \\
\hline Aptiamana & 430169 & 11.94858 & -71.3105 & 11.94331 & -71.30615 & Castilletes & 120 \\
\hline Bahiá Cocinetas & 430120 & 11.81326 & -71.38096 & NA & NA & Ware & 23 \\
\hline Bahiá Tucacas medio & 430116 & 11.91771 & -71.32802 & NA & NA & Castilletes & 19 \\
\hline Bahiá Tucacas norte & 430115 & 11.9264 & -71.31784 & NA & NA & Castilletes & 19 \\
\hline Bahiá Tucacas sur & 430117 & 11.90156 & -71.32996 & NA & NA & Castilletes & 18 \\
\hline Estacion de Policia & 430052 & 11.8512 & -71.324 & NA & NA & Ware & 22 \\
\hline Kabarauremana & 430214 & 11.97727 & -71.30439 & 11.97115 & -71.29266 & Jimol & 92 \\
\hline Kaitamana & 430118 & 11.84519 & -71.38591 & 11.85683 & -71.36547 & Jimol-Castilletes & 159 \\
\hline La Tienda & 290432 & 11.94568 & -71.36437 & 11.93286 & -71.35949 & Jimol-Castilletes & 66 \\
\hline Long & 170514 & 11.92822 & -71.34039 & 11.9261 & -71.3594 & Castilletes & 150 \\
\hline Padsua este & 430112 & 11.83023 & -71.39391 & NA & NA & Ware & 12 \\
\hline Padsua norte & 430205 & 11.83615 & -71.40053 & NA & NA & Castilletes & 15 \\
\hline Padsua sur & 430113 & 11.83142 & -71.39599 & NA & NA & Castilletes & 9 \\
\hline Paraguachon & 430121 & 11.950503 & -71.36389 & 11.944578 & -71.362183 & Jimol & 85 \\
\hline Patajau norte & 430103 & 11.9468 & -71.3321833 & 11.93099 & -71.31923 & Castilletes & 198 \\
\hline Patajau sur & 430105 & 11.93979 & -71.34218 & 11.934167 & -71.332139 & Castilletes & 113 \\
\hline Puerto Lopez sur-este & 290609 & 11.93269 & -71.31495 & NA & NA & Castilletes & 22 \\
\hline Punta Gorda norte & 430102 & 11.89371 & -71.30212 & NA & NA & Castilletes-Ware? & 9 \\
\hline Punta Gorda sur & 290617 & 11.88535 & -71.3316 & 11.881906 & -71.332682 & Castilletes & 115 \\
\hline Shavo & 430200 & 11.95189 & -71.28664 & 11.94861 & -71.28152 & Castilletes & 70 \\
\hline Shirrua & 360182 & 11.9779 & -71.42234 & 11.96593 & -71.42068 & Jimol & 26 \\
\hline Shorotiju & 430119 & 11.87934 & -71.36836 & 11.877962 & -71.35984 & Jimol-Castilletes & 128 \\
\hline Topio este & 290825 & 11.94596 & -71.2659 & 11.94896 & -71.27136 & Castilletes & 107 \\
\hline Topio oeste & 430170 & 11.962211 & -71.275608 & NA & NA & Castilletes-Ware & 28 \\
\hline Vertebrates & 170533 & 11.94982 & -71.32783 & 11.94324 & -71.32336 & Castilletes & 97 \\
\hline Yotojoro & 430203 & 11.94238 & -71.31844 & 11.93564 & -71.30763 & Castilletes & 39 \\
\hline
\end{tabular}

the unit (see Hendy et al. (2015), in this issue, for a detailed description of this assemblage).

Vertebrate paleontology The 18 most fossiliferous localities (Table 4) have yielded 572 vertebrate specimens including representatives of nine mammal 'orders' (Astrapotheria, Cetacea, Cingulata, Litopterna, Notoungulata, Pilosa, Rodentia, Sirenia, and Sprassodonta), three reptile 'orders' [Crocodilia, Testudines, and Squamata (Cadena and Jaramillo 2015)], and ten fish 'orders' (Pristiophoriformes, Orectolobiformes, Lamniformes, Carcharhiniformes, Rajiformes, Myliobatiformes, Characiformes, Siluriformes Antoine et al. (2013a), Perciformes, and Lepidosireniformes) (Tables 4, 5; Online Resource 2, Fig. 8).

Fossil flora Fossil wood fragments.

Age The invertebrate fauna of the Castilletes Formation is highly similar not only to that of the underlying Jimol Formation, but also to the Cantaure Formation (latest Early Miocene) of Venezuela. Numerous marine invertebrate taxa identified from the formation are latest Early Miocene (e.g., "Paraleptopecten" quirosensis, Cyclinella venezuelana, Glyptoactis paraguanensis, Eupleura kugleri, Cymia cocoditana, Euclia werenfelsi, Conus cf. chipolanus, and Conus talis), Middle Miocene (e.g., Modulus tamenensis), or Middle to Late Miocene (e.g., Lindapecten cf. buchivacoanus) in age. Orthaulax (see discussion for Jimol Formation) has not been recorded from the Castilletes Formation, consistent with its presently known last appearance during the earliest Middle Miocene. A mean age of $16.2 \mathrm{Ma}$ (range of $16.33 \pm 0.11 \mathrm{Ma}-16.07 \pm 0.10$ month year) is calculated for beds in the Patajau Valley near the base of the formation, on the basis of ${ }^{87} \mathrm{Sr} /{ }^{86} \mathrm{Sr}$ ratios. Beds in the middle part of the formation near Makaraipao yielded a mean ${ }^{87} \mathrm{Sr} /{ }^{86} \mathrm{Sr}$ ratio-derived age of $15.30 \mathrm{Ma}$ (range of $15.14 \pm 0.13 \mathrm{Ma}-15.43 \pm 0.09$ (Table 2). No strontium isotope ratio age estimates have yet been established for the uppermost part of the formation. A late Early Miocene to early Middle Miocene (upper Burdigalian-Langhian, 16.7-14.2 Ma) age is assigned to the Castilletes Formation on the basis of macroinvertebrate biostratigraphy and 
Jimol Formation

Composite-Lectostratotype Section

Base: $11.9779 \mathrm{~N}-71.42234 \mathrm{~W}$

Top: $11.93286 \mathrm{~N}-71.35949 \mathrm{~W}$

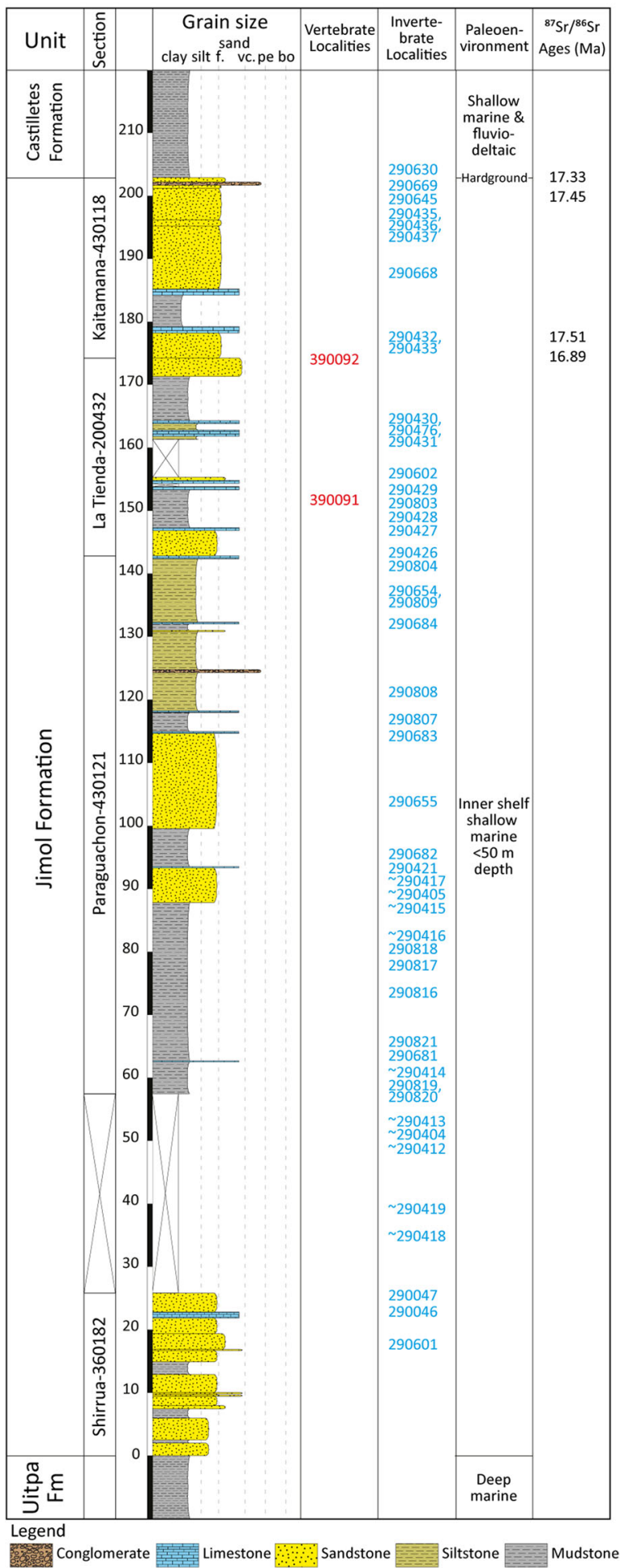

Fig. 5 Jimol Formation composite lecto-stratotype. Geographic location of the individual sections can be found in Figs. 3 and 4
${ }^{87} \mathrm{Sr} /{ }^{86} \mathrm{Sr}$ isotope chronostratigraphy (see also Hendy et al. (2015), in this issue).

Environment of deposition The Castilletes Formation was deposited in a shallow marine (estuarine, lagoonal, and shallow subtidal) to fluvio-deltaic environment with strong fluvial influence.

Correlations The Castilletes Formation correlates with the upper Cerro Pelado Formation (17.5-17 Ma sensu Quiroz and Jaramillo 2010) and Querales Formation (17-14.5 Ma sensu Quiroz and Jaramillo 2010) of the Falcon Basin in Venezuela (Fig. 2). This unit is also correlative with the Cantaure Formation (ca. 18-17 Ma) of the Paraguaná Peninsula in Venezuela.

Ware formation

Here, we introduce the Ware Formation (new), provide a formal definition, and an interpretation of depositional environments.

Name The formation is named after the wayuunnaiki (language of the indigenous Wayuu people on the Guajira Peninsula) term meaning "friend". Because the stratotype of the Ware Formation crops out along the border between Colombia and Venezuela, its name pays tribute to the friendship between both countries.

Stratotype The stratotype of the Ware Formation crops out in the hills located at the northernmost point of the Colombia-Venezuela border at $11.8512^{\circ} \mathrm{N}$ and $71.324^{\circ} \mathrm{W}$ (Figs. 4, 8, 10).

Description The formation is composed of grayish yellow fine lithic to quartz sandstone and muddy lithic to quartz sandstone, light gray mudstone, reddish gray pebbly conglomerate with sedimentary and metamorphic rock fragments, yellowish gray fossiliferous packstone, and sandy to conglomeratic beds with high fossil content. Lenticular conglomerates with sedimentary and metamorphic rock fragments, very rich in vertebrate fossils, dominate the base of the sequence; they are interbedded with mudstone, sandy mudstone, and fossiliferous fine grained lithic to quartz sandstone with planar bedding $(\sim 7 \mathrm{~m})$. Thick levels of fine lithic to quartz sandstone and sandy mudstone with cross- and planar bedding, and metric clinoforms compose the middle part of the sequence ( $\sim 15 \mathrm{~m})$. The uppermost horizon of the Ware comprises fossiliferous packstone with gravel-size fragments that vary laterally from packstone to sandy conglomerate $(\sim 3 \mathrm{~m})$ (Fig. 10).

Lower and upper boundaries The lower boundary is an angular unconformable contact with the underlying Castilletes Formation; this boundary is exposed in sections Patsua Sur-Este-430113 and Topio Oeste-430170 


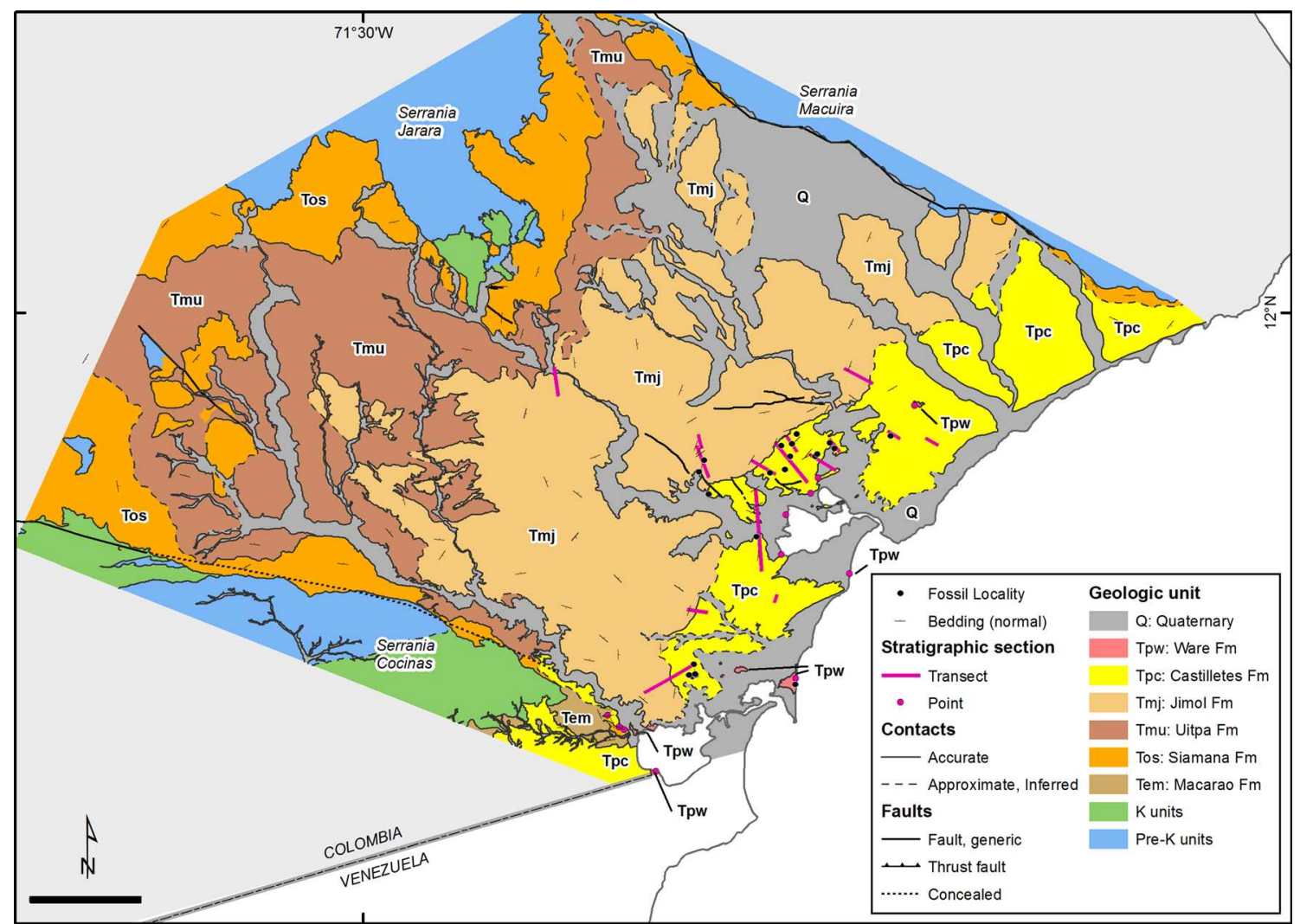

Fig. 6 Geologic map of Cocinetas Basin. Figure includes location of stratigraphic sections measured and described in this work. Scale bar is $5 \mathrm{~km}$

(Figs. 3m, v and 9). This contact frequently is eroded or not exposed, cropping out only at few sites. The upper boundary is a fossiliferous packstone in the stratotype, which varies laterally to conglomeratic packstone and pebbly conglomerate. This layer marks the youngest preserved Neogene sedimentation in the Cocinetas Basin.

Thickness and Regional Extent: The total thickness of the stratotype is $25 \mathrm{~m}$, but the formation is also mapped from small hills of apparently correlative strata distributed randomly along the eastern portion of Cocinetas Basin (Figs. 6 and 10).

Invertebrate paleontology The marine invertebrate assemblage of the Ware Formation is quite distinct relative to underlying units. Notably, the assemblage comprises a completely dissolved (moldic) aragonite fauna, whereas the shells of the calcitic forms (pectinids, ostreids) are generally well preserved as shells. Calcitic taxa such as Argopecten, Euvola, Nodipecten, Crassostrea, Plicatula, and Spondylus, and large moldic specimens of aragonitic Anodontia and Codakia are particularly distinctive in the unit. Other common moldic 'genera' with aragonitic shells include Bulla, Laevicardium, Trachycardium, and Macrocallista. More than 50 'species' of mollusks (18 gastropods and 38 bivalves), and one echinoderm have thus far been identified from the formation (see Hendy et al. (2015), in this issue, for a detailed description of this assemblage).

Vertebrate paleontology Three localities have yielded 708 specimens documenting seven mammal 'orders' (Artiodactyla, Carnivora, Cingulata, Litopterna, Notoungulata, Pilosa, and Rodentia), two reptile 'orders' (Crocodilia, Testudines), and six fish 'orders' (Carcharhiniformes, Rajiformes, Myliobatiformes, Characiformes, Perciformes, and Siluriformes Antoine et al. (2013b) (Tables 4, 5; Online Resource 2, Fig. 8).

Fossil flora Fossil wood fragments.

Age The marine invertebrate fauna of the Ware Formation shows a greater similarity with modern assemblages offshore of the Guajira Peninsula than with those of the underlying units. Few taxa provide finely resolved age constraints for the Ware Formation. Pectinids such as Amusium mortoni (Early Pliocene to earliest Pleistocene), Euvola codercola (latest Miocene to Pliocene), and Nodipecten arnoldi (Late Pliocene to Early Pleistocene) suggest an age close to the Pliocene-Pleistocene boundary. A number of internal molds of a shell similar to Acrosterigma dalli (Heilprin 1887) were also collected. Acrosterigma dalli is known only from the earliest Pleistocene of Florida and is not easily confused with other cardiid bivalves. A mean age 
Table 4 Major vertebrate fossiliferous localities for the Jimol, Castilletes, and Ware formations

\begin{tabular}{|c|c|c|c|c|c|c|}
\hline ID & Latitude & Longitude & Strat section ID & Strat section name & Formation & Stratigraphic meter \\
\hline 130023 & 11.9361 & -71.3284 & 430103 & Patajau Norte & Castilletes & 78 \\
\hline 130024 & 11.9348 & -71.3344 & 430103 & Patajau Sur & Castilletes & 80 \\
\hline 130025 & 11.9498 & -71.2853 & 430200 & Shavo & Castilletes & 21 \\
\hline 150166 & 11.852 & -71.3661 & 430118 & Kaitamana & Castilletes & 73 \\
\hline 150167 & 11.9469 & -71.3101 & 430169 & Aiptiamana & Castilletes & 23 \\
\hline 290632 & 11.9458 & -71.3299 & 430103 & Patajau Norte & Castilletes & 28 \\
\hline 340071 & 11.9447 & -71.3083 & 430203 & Yotojoro & Castilletes & 26 \\
\hline 340072 & 11.9413 & -71.3161 & 430203 & Yotojoro & Castilletes & 10 \\
\hline 390090 & 11.9261 & -71.3594 & 430103 & La Tienda & Castilletes & 72 \\
\hline 390091 & 11.9399 & -71.3614 & 290432 & La Tienda & Jimol & 11 \\
\hline 390092 & 11.9351 & -71.3634 & 290432 & La Tienda & Jimol & 35 \\
\hline 390093 & 11.9089 & -71.3401 & 170514 & Long & Castilletes & 128 \\
\hline 390094 & 11.9465 & -71.3255 & 430103 & Vertebrates & Castilletes & 46 \\
\hline 390126 & 11.8525 & -71.3676 & 430118 & Kaitamana & Castilletes & 83 \\
\hline 430053 & 11.8512 & -71.3241 & 430118 & Kaitamana & Castilletes & 97 \\
\hline 430202 & 11.8568 & -71.3655 & 430118 & Kaitamana & Castilletes & 150 \\
\hline 470058 & 11.9506 & -71.3237 & 430103 & Patajau Norte & Castilletes & 28 \\
\hline 470059 & 11.8487 & -71.3243 & 430052 & Estación de Policia & Ware & 2 \\
\hline 470062 & 11.8487 & -71.3243 & 430052 & Estación de Policia & Ware & 5 \\
\hline 470065 & 11.9261 & -71.3594 & 430103 & La Tienda & Castillets & 69 \\
\hline 470066 & 11.9465 & -71.3255 & 430103 & Patajau Norte & Castilletes & 45 \\
\hline 490006 & 11.9423 & -71.3152 & 430203 & Yotojoro & Castilletes & 17 \\
\hline
\end{tabular}

of 3.2 Ma (range of $3.40 \mathrm{Ma}$ to $2.78 \mathrm{Ma}$ ) is calculated for the shell bed at the top of the formation from ${ }^{87} \mathrm{Sr} /{ }^{86} \mathrm{Sr}$ ratios (Table 2). A Late Pliocene (Piacenzian) age is assigned to the Ware Formation on the basis of macroinvertebrate biostratigraphy and ${ }^{87} \mathrm{Sr} /{ }^{86} \mathrm{Sr}$ isotope chronostratigraphy.

Environment of deposition The base of the Ware Formation was deposited in a fluvio-deltaic environment, whereas the marine invertebrate assemblage at the top of the unit contains taxa typical of exposed open-ocean shoreface and nearshore settings, but with proximity to coral reef habitats.

Correlations: The Ware Formation correlates with the San Gregorio Formation (ca. 4-2 Ma sensu Quiroz and Jaramillo 2010) in the Falcon Basin in Venezuela (Fig. 2).

\section{Discussion}

\section{Stratigraphy}

We propose three major changes to the previous stratigraphy of Cocinetas Basin: (1) a new definition for the Jimol-Castilletes formational boundary, (2) a new definition of the upper boundary of the Castilletes Formation, and therefore, a new definition of both the Jimol and Castilletes
Formations, and (3) a new Pliocene lithostratigraphic unit, the Ware Formation.

The upper boundary of the Jimol Formation was defined by Rollins (1965) as the limit between a sandy claystone at the top of Jimol and an oyster-bearing limestone at the base of the Castilletes. However, oyster-bearing limestones are laterally discontinuous and common both at the top of the Jimol and throughout the lower Castilletes sensu Rollins (see sections 360182, 290432 and 430121 in Fig. 3a-c). Therefore, they are not a good criterion for a boundary. The contact between the Jimol and Castilletes Formations is very transitional, and detailed stratigraphy shows a gradual environmental change between the two units (Figs. 5, 6, and 7, Online Resource 1). The Jimol Formation is dominated by coarse detritic and calcareous lithologies with fewer interbedded muddy levels. In contrast, the Castilletes Formation is dominated by mudstones with fewer interbedded, thin, calcareous, and coarse detritic levels that form ridges in the landscape. We propose this facies change as the new limit between these units, with a conspicuous and laterally extensive hardground surface at the top of a transgressive calcareous layer as the boundary surface between the two formations (sections 290432, 430214, 430118, 430119, 430103, and 170533 in Fig. 3b, d-f, h and i). 
Table 5 Major groups of vertebrate taxa identified from the jimol, castilletes and ware formations

\begin{tabular}{|c|c|c|c|c|c|}
\hline Class & Order & Family & Jimol & Castilletes & Ware \\
\hline Mammalia & Artiodactyla & Camelidae & & & $x$ \\
\hline Mammalia & Astrapotheria & Astrapotheriidae & & $x$ & \\
\hline Mammalia & Carnivora & Procyonidae & & & $\times$ \\
\hline Mammalia & Cetacea & Odontoceti & & $x$ & \\
\hline Mammalia & Cetacea & Mysticeti & & $x$ & \\
\hline Mammalia & Cingulata & Glyptodontidae & & $x$ & $x$ \\
\hline Mammalia & Cingulata & Pampatheriidae & & $x$ & $x$ \\
\hline Mammalia & Litopterna & Macraucheniidae & & $x$ & \\
\hline Mammalia & Litopterna & Proterotheriidae & & $x$ & $x$ \\
\hline Mammalia & Notoungulata & Leontinidae & & $x$ & \\
\hline Mammalia & Notoungulata & Toxodontidae & & $x$ & $x$ \\
\hline Mammalia & Notoungulata & Interatheriidae & & $\times$ & \\
\hline Mammalia & Pilosa & Megalonychidae & & & $x$ \\
\hline Mammalia & Pilosa & Megatheriidae & & $\times$ & $x$ \\
\hline Mammalia & Pilosa & Mylodontidae & & & $\times$ \\
\hline Mammalia & Rodentia & Caviidae & & & $\times$ \\
\hline Mammalia & Rodentia & Dinomyidae & & $x$ & \\
\hline Mammalia & Rodentia & Erethizontidae & & & $\times$ \\
\hline Mammalia & Rodentia & Hydrochoeridae & & & $x$ \\
\hline Mammalia & Sirenia & & & $x$ & \\
\hline Mammalia & Sparassodonta & & & $x$ & \\
\hline Reptilia & Crocodilia & Alligatoridae & & $\times$ & $x$ \\
\hline Reptilia & Crocodilia & Crocodylidae & $x$ & $x$ & $x$ \\
\hline Reptilia & Crocodilia & Gavialidae & $\times$ & $\times$ & \\
\hline Reptilia & Squamata & Boidae & & $\times$ & \\
\hline Reptilia & Testudines & Podocnemididae & & $x$ & $x$ \\
\hline Reptilia & Testudines & Chelidae & & $\times$ & \\
\hline Aves & & & & $x$ & $x$ \\
\hline Actinopterygii & Characiformes & Characidae & & $x$ & $x$ \\
\hline Actinopterygii & Characiformes & Cynodontidae & & & $x$ \\
\hline Actinopterygii & Characiformes & Serrasalmidae & & $x$ & $x$ \\
\hline Actinopterygii & Perciformes & Cichlidae & & & $x$ \\
\hline Actinopterygii & Perciformes & Sciaenidae & & $x$ & $x$ \\
\hline Actinopterygii & Perciformes & Sparidae & & $x$ & \\
\hline Actinopterygii & Perciformes & Sphyraenidae & & $x$ & \\
\hline Actinopterygii & Siluriformes & Ariidae & & $x$ & \\
\hline Actinopterygii & Siluriformes & Callichthyidae & & $x$ & \\
\hline Actinopterygii & Siluriformes & Doradidae & & $x$ & $x$ \\
\hline Actinopterygii & Siluriformes & Pimelodidae & & $x$ & $\times$ \\
\hline Chondrichthyes & Carcharhiniformes & Carcharhinidae & $\times$ & $\times$ & $\times$ \\
\hline Chondrichthyes & Carcharhiniformes & Hemigaleidae & $\times$ & $\times$ & \\
\hline Chondrichthyes & Carcharhiniformes & Sphyrnidae & & $x$ & $\times$ \\
\hline Chondrichthyes & Lamniformes & Lamnidae & $\times$ & $\times$ & \\
\hline Chondrichthyes & Lamniformes & Otodontidae & & $\times$ & \\
\hline Chondrichthyes & Myliobatiformes & Dasyatidae & & $x$ & \\
\hline Chondrichthyes & Myliobatiformes & Myliobatidae & $\times$ & $x$ & $x$ \\
\hline Chondrichthyes & Myliobatiformes & Rhinopteridae & & $x$ & \\
\hline Chondrichthyes & Orectolobiformes & Ginglymostomatidae & & $x$ & \\
\hline
\end{tabular}


Table 5 continued

\begin{tabular}{|c|c|c|c|c|c|}
\hline Class & Order & Family & Jimol & Castilletes & Ware \\
\hline Chondrichthyes & Pristiophoriformes & Pristiophoridae & & $x$ & \\
\hline Chondrichthyes & Rajiformes & Pristidae & & $x$ & $x$ \\
\hline Chondrichthyes & Rajiformes & Rhynchobatidae & & $\times$ & \\
\hline Chondrichthyes & Rajiformes & Rhynobatidae & & $x$ & \\
\hline Chondrichthyes & Squaliformes & Dalatiidae & $x$ & & \\
\hline Sarcopterygii & Lepidosireniformes & Lepidosirenidae & & $x$ & \\
\hline
\end{tabular}

In addition, we propose a new lithostratigraphic unit based on field observations and ${ }^{87} \mathrm{Sr} /{ }^{86} \mathrm{Sr}$ geochronological results, which reveal a large unconformity within the upper portion of the Castilletes Formation of Rollins (1965). This unconformity encompasses a gap in the sedimentary record between 14.5 and 3.5 Ma. We redefine the Castilletes Formation and propose the new Ware Formation as the sub-horizontal fluvio-deltaic to shallow marine deposits overlying this angular unconformity. Ware deposits are distributed along the eastern margin of the Cocinetas Basin, cropping out as isolated hills with sub-horizontal strata, which are essentially remnants of what would have been a widely distributed unit (Fig. 6).

\section{Paleoenvironments}

The Jimol Formation accumulated in a shallow marine environment although it expresses the overprint of rapid oscillations of relative sea level. Intervals of marine flooding led to deposition of wackestone to packstone biosparites with diverse shallow marine invertebrate communities, including thick oyster banks. Periods of lowered relative sea level are dominated by coarse calcareous and lithic sandstone with cross- and planar bedding deposited in shore-face environments and massive mudstone deposited in foreshore to backshore environments. The Castilletes Formation also exhibits these depositional sequences, but in a more proximal setting, marking the transition to a fluvio-deltaic dominated environment. Transgressive intervals are dominated by coquina, oyster banks, and shore-face deposits, whereas regressive intervals are characterized by muddy facies of estuarine and fluvio-deltaic plain settings and sandy facies that represent deltaic channels. The vertebrate fossil assemblage of the Castilletes Formation is dominated by large crocodiles, large turtles, and grazing and browsing herbivores, which suggests the presence of year-round fresh-water bodies including rivers, swamps, and lakes as well as grasslands and forests up to $14.5 \mathrm{Ma}$. The Ware Formation is dominated by sandstone and muddy sandstone, mudstone, pebbly conglomerate, and packstone to conglomeratic packstone lithologies indicating a fluvio-deltaic environment. Its extensive vertebrate fossil record, including crocodiles, turtles, and grazing and browsing herbivores, also suggests the existence of year-round bodies of fresh water, much like those in the Castilletes Formation. These deposits and their associated fauna are in stark contrast to modern environments of the Cocinetas Basin, which are extremely dry, with a prolonged dry season ( $\sim 11$ months), dominated by xerophytic vegetation and lacking large rivers or year-round bodies of fresh water. This contrast suggests that a major change in the landscape occurred over the past 2.5-3 m.y., leading to the extant aridification of the region (Fig. 8).

Great american biotic interchange (GABI)

Despite important advances in the Neogene Neotropical paleontology, the Neotropical vertebrate fossil record is still scarce when compared with temperate regions (Carrillo et al. 2014; MacFadden 2006a). There are only five well-studied faunal associations in the Neogene of the Neotropics (Fig. 10) although it is a vast territory (twice the area of continental Europe) with high levels of biodiversity. Sites include the Early Miocene terrestrial deposits of the Panamanian isthmus (MacFadden 2006a, b, 2009, 2010; MacFadden and Higgins 2004; Rincon et al. 2012; Whitmore Stewart 1965); the Middle Miocene deposits from La Venta (Kay et al. 1997); the Late Miocene vertebrate deposits from Acre (Cozzuol, 2006; Frailey 1986; Negri et al. 2010; Ribeiro et al. 2013), the Early to Late Miocene deposits in the Peruvian Amazon (Antoine et al. 2007, 2013; Marivaux et al. 2012; Negri et al. 2010; Tejada-Lara et al. 2014), and the Late Miocene ( 6-10 Ma) and Pliocene (2-4 Ma) deposits of the Urumaco sequence, in particular the Urumaco, Codore, and San Gregorio Formations in north western Venezuela (e.g., Aguilera 2004; Aguilera and Rodriguez de Aguilera 2001; Forasiepi et al. 2014; Head et al. 2006; Linares 2004; Quiroz and Jaramillo 2010; Sánchez-Villagra and Aguilera 2006; Sánchez-Villagra et al. 2003; Sánchez-Villagra 2006; Sánchez-Villagra and Clack 2004; Vucetich et al. 2010; Winkler and Sánchez-Villagra 2006) (Fig. 10) 


\section{Castilletes Formation}

Composite-Lectostratotype Section

Base: $11.9468 \mathrm{~N}-71.33218 \mathrm{~W}$

Top: $11.89371 \mathrm{~N}-71.30212 \mathrm{~W}$

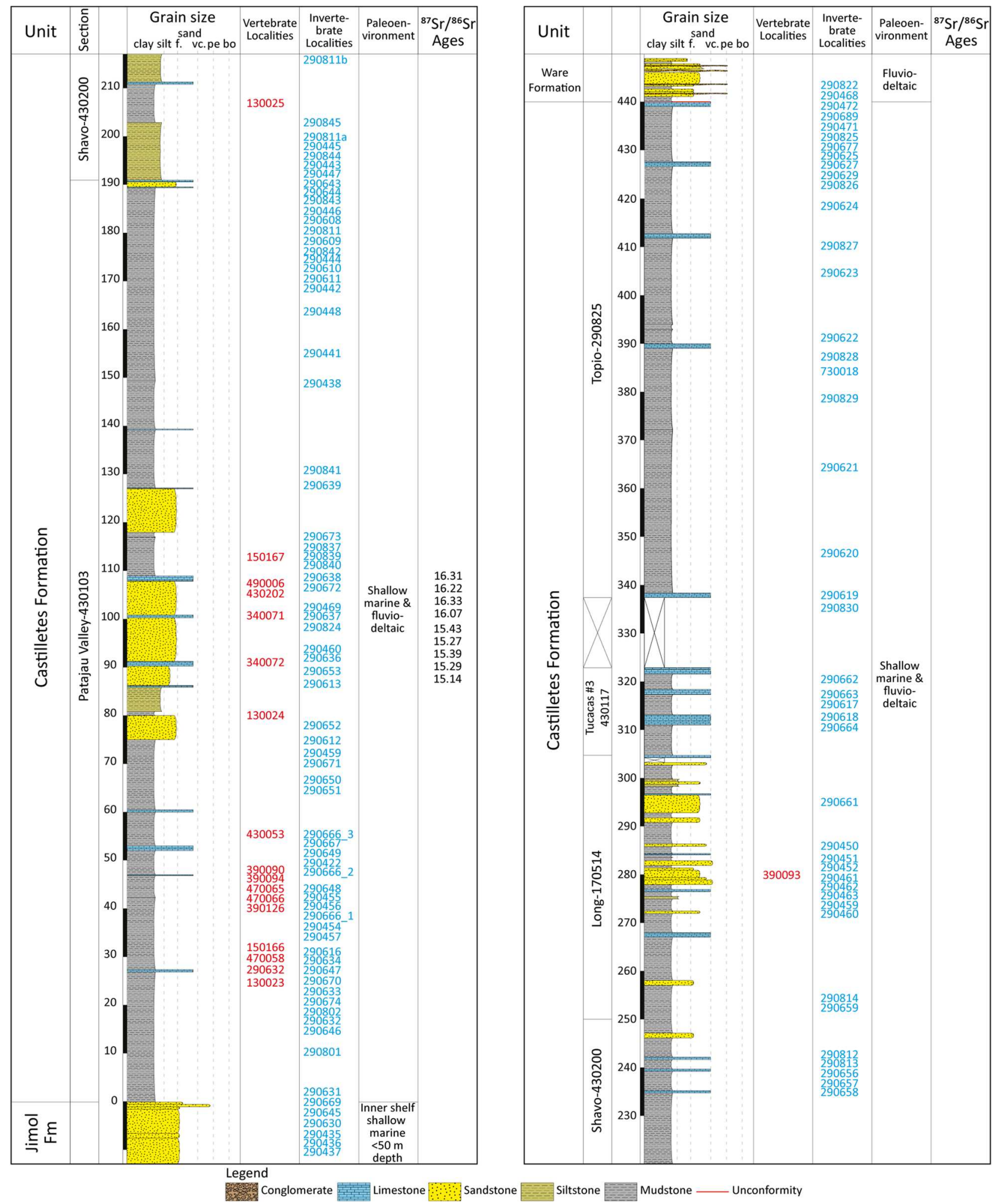

Fig. 7 Castilletes Formation composite lecto-stratotype. Geographic location of the individual sections can be found in Figs. 3 and 4 

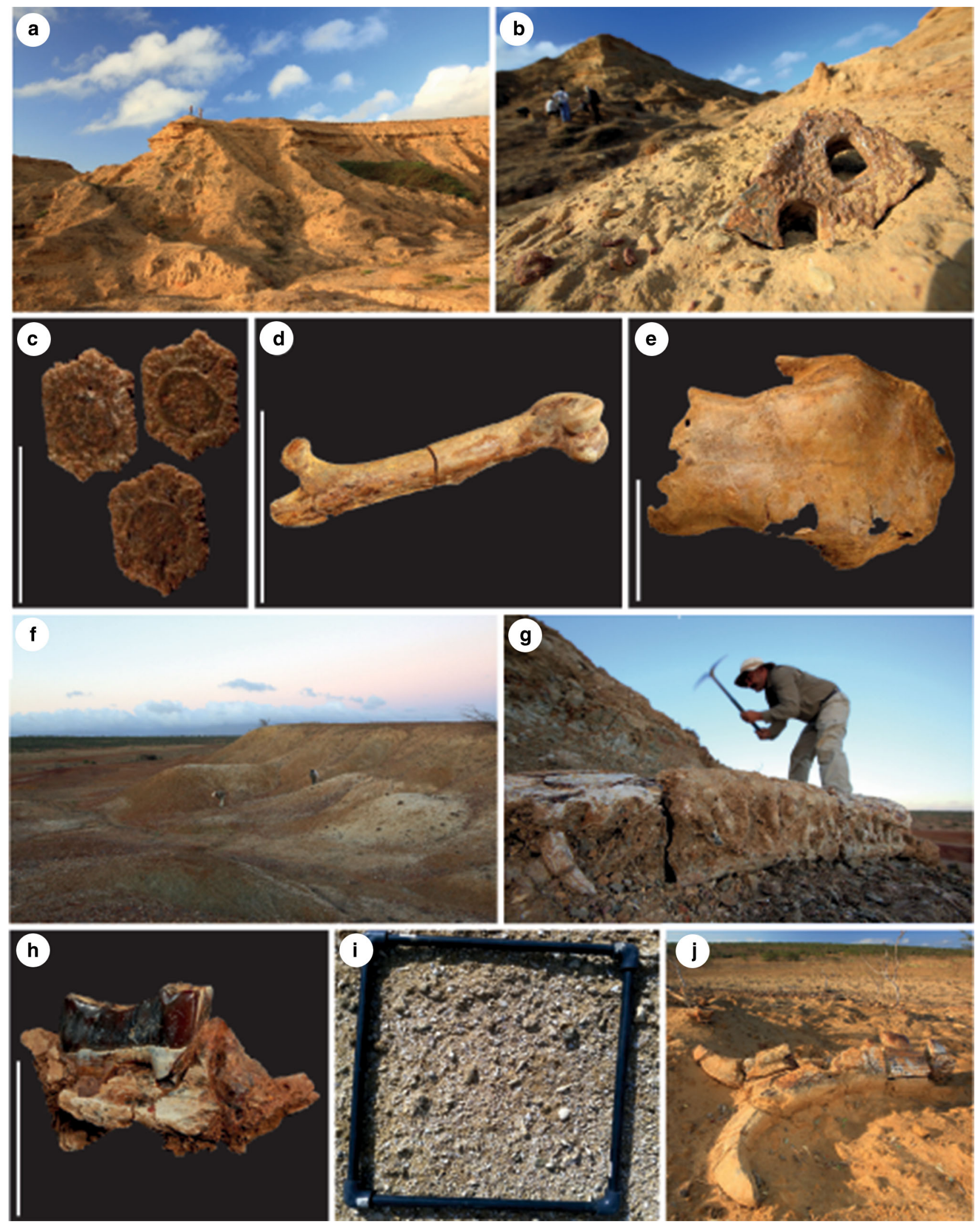
4Fig. 8 Main fossiliferous localities and representative fossils from the Ware and Castilletes formations. (a-e) Ware Formation; a Locality 470062; photograph shows the characteristic subhorizontal position of the Ware Formation beds; this site correspond to the stratotype section of the Ware Formation mainly composed by conglomerates at the base, sandstones, and muddy sandstones in the middle, and a thick fossiliferous packstone level at the top; (b) braincase of Crocodylidae (STRI-ID34591); (c) Glyptodontidae osteoderms (STRI-ID12928), scale bar $5 \mathrm{~cm}$; (d) Hydrochoeridae femur (STRI-ID34315), scale bar $10 \mathrm{~cm}$; and (e) Megalonychidae skull (STRI-ID12924), scale bar $10 \mathrm{~cm}$. (f-j) Castilletes Formation; (f) Locality 390094, typical valley and ridge topography of Castilletes Formation formed by the thick muddy levels with hard calcareous and sandy levels on top; (g) Gavialidae rostrum (STRI-ID34540); (h) Leontinidae lower molar (STRI-ID34312), scale bar $5 \mathrm{~cm}$; (i) fossiliferous mudstone covered with gastropods; (j) Locality 470058 with a mandible of Astrapotheriidae (STRI-ID34383). Photographs taken by Christian Ziegler (a-j)

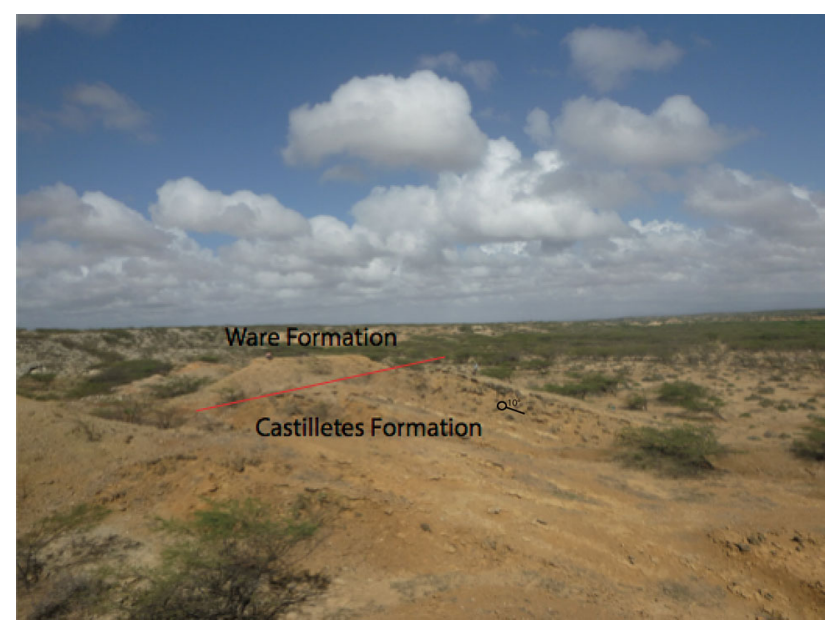

Fig. 9 Angular unconformity between the Castilletes and Ware formations $\left(11.83142^{\circ} \mathrm{N}\right.$ and $\left.71.39599^{\circ} \mathrm{W}\right)$

The late Neogene witnessed one of the largest biogeographic events in Earth's history, the Great American Biotic Interchange (GABI). This episode of species dispersal between the previously disconnected landmasses of South America and Central-North America was the product of the complex rise of the isthmus of Panama, which started ca. 10-12 Ma (Jaramillo et al. 2013; Montes et al. 2012; Sepulchre et al. 2014) and culminated with the full rise of the isthmus ca. $3.5 \mathrm{Ma}$ (Coates et al. 2003, 2004). There is an extensive record of publications on GABI over many decades (Leigh et al. 2014; Marshall et al. 1982; Stehli and Webb 1985; Verzi and Montalvo 2008; Wallace 1876; Webb 1976, 1985, 1991, 2006; Woodburne 2010). However, the fossil record of South America that has been used to understand GABI has been mostly from temperate parts of the continent (Argentina, Chile, and Bolivia) (Carrillo et al. 2014). Furthermore, the biochronology that is applied throughout South America, known as South American Land Mammal Ages (SALMAs), is largely based on these temperate regions (Fig. 10). The timing and dynamics of

\section{Ware Formation \\ Stratotype Section}

Estacion de Policia Locality-430052

$11.85120 \mathrm{~N}-71.32400 \mathrm{~W}$

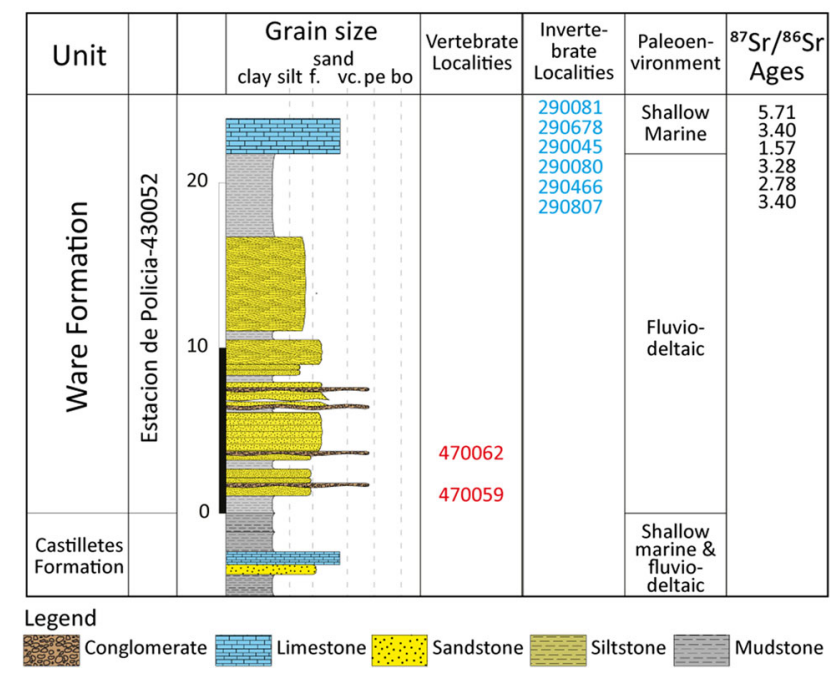

Fig. 10 Ware Formation Stratotype. Geographic location of the individual sections can be found in Fig. 3 and Online Resource 1

GABI, however, cannot be fully understood without the inclusion of the tropical region, because the point of connection between the two landmasses was within the tropics (Fig. 11).

A detailed study of the rich terrestrial fossil record preserved in the Cocinetas Basin will serve to fill two major gaps. First, the assemblages of the Early-Middle Miocene of the Jimol and Castilletes Formations are similar in age to geographically proximal Panamanian faunas that lived on the other side of the seaway on Central American landmasses. These Panamanian assemblages already had a mixture of North American-derived taxa, mostly mammals (MacFadden 2006a, b, 2009, 2010; MacFadden et al. 2012; MacFadden and Higgins 2004; Rincon et al. 2012, 2013; Slaughter 1981; Whitmore and Stewart 1965) and South American-derived taxa, mostly crocodiles, turtles, snakes, and plants (Cadena et al. 2012; Hastings et al. 2013; Head et al. 2012; Jaramillo et al. 2014). Furthermore, the Jimol and Castilletes Formations record span the full range of the Middle Miocene climatic optimum (Zachos et al. 2001), the last event of major warming during the Cenozoic. Analyses of the terrestrial and aquatic vertebrate paleoecology and the palynology of these units will contribute to our understanding of how tropical ecosystems respond to global warming.

Second, the fossil record of the Ware Formation is of particular interest because it constitutes the most proximal sequence in both time (Late Pliocene) and space $(600 \mathrm{~km}$ away) to the Panamanian isthmus and its final rise at 


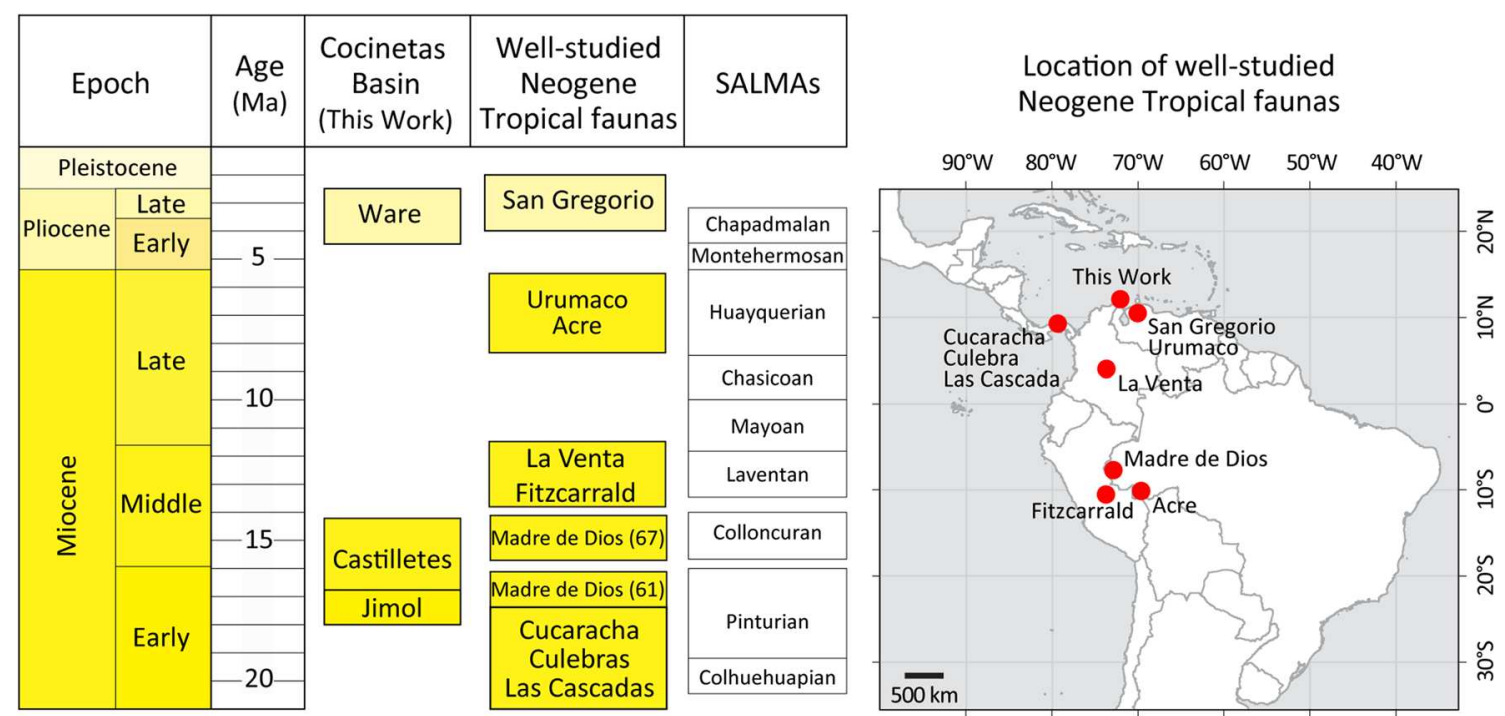

Fig. 11 Temporal and geographic distribution of the only well-studied Neogene vertebrate localities within the Neotropical region

3.5 Ma. Together with the San Gregorio Formation in western Venezuela (Vucetich et al. 2010; Castro et al. 2014; Forasiepi et al. 2014), it will provide a window into the most critical interval in GABI's history, the Late Pliocene (Woodburne 2010).

\section{Conclusions}

The Jimol, Castilletes, and Ware Formations record the paleoenvironmental transition of the Cocinetas Basin from a shallow marine shelf to a fluvio-deltaic system. New stratigraphic and geochronological data result in a revised definition of the Neogene lithostratigraphic units in the Cocinetas Basin. The geologic record shows the Neogene in Cocinetas Basin as a shallow marine to fluvio-deltaic system characterized by successive transgressions and regressions. This geological reconnaissance has also highlighted tremendously diverse and important fossil assemblages throughout the Jimol, Castilletes, and Ware Formations. These new fossil data are of great value for paleobiogeographic, paleogeographic, paleoceanographic, and paleoenvironmental interpretations. The faunal and floral fossil record of the Cocinetas Basin indicates a humid ecosystem during the Neogene and reveals that drastic climate change that occurred during the past two to three million years.

Acknowledgments The Smithsonian Institution, the National Geographic Society, the Anders Foundation, Gregory D. and Jennifer Walston Johnson, Universidad del Norte, lab of Marcelo R. SánchezVillagra at the University of Zurich, the Swiss SNF 31003A-149605 to M. R. Sánchez-Villagra, and the National Science Foundation (Grant EAR 0957679) helped to support this work. Thanks to Carlos Rosero for managing all the logistics in the field, and to Liliana
Londoño and Maria Ines Barreto for administrative and logistic support. Thanks to Gabriel Aguirre for preliminary identification on cetacean specimens. Thanks to Christian Ziegler for pictures on Fig. 8. We thank the reviewers Analia Forasiepi, Marcelo Sánchez Villagra, German Bayona and Pierre-Olivier Antoine for their helpful comments on the manuscript. Additional funding to A. Hendy was provided by the Jon A. and Beverly L. Thompson Endowment, Florida Museum of Natural History, C. Martínez by Fulbright-Colciencias, F. Moreno, A. Cardenas, and N. Hoyos by Colciencias (Fondo para la Ciencia, la Tecnología y la Innovación), and Juan Carrillo by Swiss National Fund SNF 31003A-149605. Thanks to the communities of Warpana, Patajau, Aulechit, Nazareth, Wososopo, Sillamana, Paraguachon, La Flor de la Guajira, and Ipapura. Thanks to the Colombian National Police (Castilletes base) and the Colombian Army (La Flor de la Guajira and Cerro de la Teta). We express special thanks to our drivers, Grillo, Lalo, and Medardo.

\section{References}

Aguilera, O. (2004). Tesoros Paleontológicos de Venezuela, Urumaco, Patrimonio Natural de la Humanidad. Caracas: Editorial Arte.

Aguilera, O., Lundberg, J., Birindelli, J., Sabaj Pérez, M., Jaramillo, C., \& Sánchez-Villagra, M. R. (2013a). Palaeontological evidence for the last temporal occurrence of the ancient western Amazonian River Outflow into the Caribbean. PLoS One, 8(9), e76202.

Aguilera, O., Moraes-Santos, H., Costa, S., Ohe, F., Jaramillo, C., \& Nogueira, A. (2013b). Ariid sea catfish from the coeval Pirabas (Northeastern Brazil), Cantaure, Castillo (Northwestern Venezuela) and Castilletes (North Colombia) formations (Early Miocene), with description of three new species. Swiss Journal of Palaeontology, 132(1), 45-68.

Aguilera, O., \& Rodriguez de Aguilera, D. (2001). An exceptional coastal upwelling fish assemblage in the Caribbean Neogene. Journal of Paleontology, 75(3), 732-742.

Antoine, P. O., Roddaz, M., Brichau, S., Tejada-Lara, J., SalasGismondi, R., Altamirano, A., et al. (2013). Middle Miocene vertebrates from the Amazonian Madre de Dios subandean zone, Peru. Journal of South American Earth Sciences, 42, 91-102. 
Antoine, P. O., Salas-Gismondi, R., Baby, P., Benammi, M., Brusset, S., De Franceschi, D., et al. (2007). The middle Miocene (Laventan) Fitzcarrald fauna, Amazonian Peru. Cuadernos del Museo Geominero, 8, 19-24.

Becker, L.E., \& Dusenbury, A.N. (1958). Mio-oligocene (Aquitanian) foraminifera from the Goajira Peninsula, Colombia. Cushman Foundation for Foraminiferal Research. (Special Publication N.4).

Burgl, H. (1960). Geología de la peninsula de la Guajira. Boletín Geológico, 6, 129-168.

Burke, W. H., Denison, R. E., Hetherington, E. A., Koepnick, R. B., Nelson, H. F., \& Otto, J. B. (1982). Variation of seawater $87 \mathrm{Sr} /$ 86Sr throughout Phanerozoic time. Geology, 10(10), 516-519.

Cadena, E., Bourque, J., Rincon, A. F., Bloch, J. I., Jaramillo, C. A., \& MacFadden, B. J. (2012). New Turtles (Chelonia) from the late eocene through late miocene of the Panama Canal Basin. Journal of Paleontology, 86(3), 539-557.

Cadena, E., \& Jaramillo, C. (2015). Early to middle Miocene turtles from the northernmost tip of South America: giant testudinids, chelids, and podocnemidids from the Castilletes Formation, Colombia. Ameguiniana v. in press.

Carrillo, J. D., Forasiepi, A., Jaramillo, C., \& Sánchez-Villagra, M. R. (2014). Neotropical mammal diversity and the Great American Biotic Interchange: spatial and temporal variation in South America's fossil record. Front: Genet. doi:10.3389/fgene.2014. 00451.

Castro, M. C., Carlini, A. A., Sánchez, R., \& Sánchez-Villagra, M. R. (2014). A new Dasypodini armadillo (Xenarhtra: cingulata) from San Gregorio Formation, Pliocene of Venezuela: affinities and biogeographic interpretations. Naturwissenschaften, 101(2), $77-86$.

Chaisson, W. P., \& D'Hondt, S. L. (2000). Neogene planktonic foraminifer biostratigraphy at Site 999, western Caribbean Sea. Proc. ODP, Sci. Results, 165, 19-56.

Coates, A. G., Aubry, M., Berggren, W. A., Collins, L. S., \& Kunk, M. (2003). Early Neogene history of the Central American arc from Bocas del Toro, western Panama. Geological Society of America Bulletin, 115(3), 271-287.

Coates, A. G., Collins, L. S., Aubry, M., \& Berggren, W. A. (2004). The geology of the Darien, Panama, and the late MiocenePliocene collision of the Panama Arc with northwestern South America. Geological Society of America Bulletin, 116(11-12), $1327-1344$.

Cozzuol, M. A. (2006). The Acre vertebrate fauna: age, diversity, and geography. Journal of South American Earth Sciences, 21(3), 185-203.

Díaz de Gamero, M. L. (1974). Microfauna y edad de la Formación Cantaure, Penınsula de Paraguaná, Venezuela. Boletín Informativo de la Asociación Venezolana de Geología, Minería y Petroleo, 17, 41-47.

Dunham, R. (1962). Classification of carbonate rocks according to depositional texture. Classification of carbonate rocks, a symposium. American Association of Petroleum Geologist, Memoir 1, Tulsa, Oklahoma.

Folk, R. (1980). Petrology of sedimentary rocks. Austin: Hemphill Publishing Company.

Forasiepi, A. M., Soibelzon, L. H., Suarez Gomez, C., Sánchez, R., Quiroz, L. I., Jaramillo, C., \& Sánchez-Villagra, M. R. (2014). Carnivorans at the great american biotic interchange: New discoveries from the northern Neotropics. Naturwissenschaften, 101(11), 965-974.

Frailey, C. D. (1986). Late Miocene and Holocene mammals, exclusive of the Notoungulata, of the Rio Acre Region, western Amazonia. Contributions in Science., 374, 1-46.

Hastings, A. K., Bloch, J. I., Jaramillo, C. A., Rincon, A. F., \& MacFadden, B. J. (2013). Systematics and biogeography of crocodylians from the Miocene of Panama. Journal of Vertebrate Paleontology, 33(2), 239-263.

Head, J. J., Rincon, A. F., Suarez, C., Montes, C., \& Jaramillo, C. (2012). Fossil evidence for earliest Neogene American faunal interchange: boa (Serpentes, Boinae) from the early Miocene of Panama. Journal of Vertebrate Paleontology, 32(6), $1328-1334$.

Head, J. J., Sánchez-Villagra, M. R., \& Aguilera, O. A. (2006). Fossil snakes from the Neogene of Venezuela (Falcón State). Journal of Systematic Palaeontology, 4(3), 233-240.

Heilprin, A. (1887). Explorations on the West Coast of Florida and in the okeechobee wilderness: with special reference to the geology and zoology of the Floridian Peninsula. Transactions of the Wagner Free Institute of Science of Philadelphia, 1, 1-134.

Hendy, A.J.W., Jones, D.S., Moreno, F., Zapata, V., Jaramillo, C. (2015). Neogene molluscs, shallow-marine paleoenvironments, and chronostratigraphy of the Guajira Peninsula, Colombia. Swiss Journal of Palaeontology (this issue). doi:10.1007/ s13358-015-0074-1.

Howarth, R. J., \& McArthur, J. M. (1997). Statistics for strontium isotope stratigraphy. A robust LOWESS fit to the marine $\mathrm{Sr}$ isotope curve for 0-206 Ma, with look-up table for the derivation of numerical age. Journal of Geology, 105(4), 441-456.

Irving, E. (1971). La evolución estructural de los Andes más septentrionales de Colombia. Boletín Geológico, 19(2), 1-90.

Jaramillo, C., Moreno, E., Ramirez, V., da Silva, S., Barrera, A., Adhara, B., \& Hoyos, N. (2014). Palynological record of the last 20 Million years in Panama. Monographs in Systematic Botany from the Missouri Botanical Garden, in press.

Jaramillo, C. A., Zavada, M., Ortiz, J., Pardo, A., \& Ochoa, D. (2013). The Biogeography of the Araucarian dispersed pollen Cyclusphaera. International Journal of Plant Sciences, 174(3), 489-498.

Jung, P. (1965). Miocene mollusca from the Paraguaná Peninsula, Venezuela. Bulletins of American Paleontology, 49, 389-652.

Kay, R. F., Madden, R. H., Cifelli, R. L., \& Flynn, J. J. (1997). Vertebrate paleontology in the neotropics: The Miocene Fauna of La Venta, Colombia. Washington: Smithsonian Institution Press.

Kirby, M.X., Jones, D.S., \& Ávila, S.P. (2007). Neogene Shallowmarine paleoenvironments and preliminary strontium isotope chronostratigraphy of Santa Maria Island, Azores. In S.P. Ávila and A.M. De Frias Martin (Eds.), Proceedings of the 1st "Atlantic Islands Neogene" International Congress, Ponta Delgada, 12-14 June 2006. Açoreana, Suplemento, 5, 112-115.

Kirby, M. X., Jones, D. S., \& MacFadden, B. J. (2008). Lower Miocene stratigraphy along the Panama Canal and its bearing on the Central American Peninsula. PLoS One,. doi:10.1371/ journal.pone.0002791.

Leigh, E. G., O’Dea, A., \& Vermeij, G. J. (2014). Historical biogeography of the Isthmus of Panama. Biological Reviews, 89, 148-172. doi:10.1111/brv.12048.

Linares, O. J. (2004). Bioestratigrafía de la fauna de mamíferos de las formaciones Socorro, Urumaco y Codore (Mioceno medioPlioceno temprano, de la región de Urumaco, Falcon, Venezuela. Paleobiología Neotropical, 1, 1-26.

Lockwood, J.P. (1965). Geology of the Serranía de Jarara area. Guajira Peninsula, Colombia. Doctoral Thesis, Princeton University.

Macellari, C.E. (1995). Cenozoic sedimentation and tectonics of the southwestern Caribbean pull-apart basin, Venezuela and Colombia. In A.J. Tankard, R. Suarez Soruco, H.J. Welsink (Eds.), Petroleum basins of South America. (Vol. 62, pp. 757-780). Tulsa, OK, United States: American Association of Petroleum Geologists. 
MacFadden, B. J. (2006a). Extinct mammalian biodiversity of the ancient New World tropics. Trends in Ecology \& Evolution, 21(3), 157-165.

MacFadden, B. J. (2006b). North American Miocene land mammals from Panama. Journal of Vertebrate Paleontology, 26(3), $720-734$.

MacFadden, B. J. (2009). Three-toed browsing horse Anchitherium (Equidae) from the Miocene of Panama. Journal of Paleontology, 83(3), 489-492.

MacFadden, B. J., Foster, D. A., Rincon, A. F., Morgan, G. S., \& Jaramillo, C. (2012). The new world tropics as a cradle of biodiversity during the early miocene: calibration of the centenario Fauna From Panama. Geological Society of America Abstracts with Programs, 44(7), 163.

MacFadden, B. J., \& Higgins, P. (2004). Ancient ecology of 15-million-year-old browsing mammals within C3 plant communities from Panama. Oecologia, 140(1), 169-182.

MacFadden, B. J., Kirby, M. X., Rincon, A., Montes, C., Moron, S., Strong, N., \& Jaramillo, C. (2010). Extinct peccary "Cynorca" occidentale (Tayassuidae, Tayassuinae) from the Miocene of Panama and correlations to North America. Journal of Paleontology, 84(2), 288-289.

Marivaux, L., Salas-Gismondi, R., Tejada, J., Billet, G., Louterbach, M., Vink, J., et al. (2012). A platyrrhine talus from the early Miocene of Peru (Amazonian Madre de Dios Sub-Andean Zone). Journal of Human Evolution, 63(5), 696-703.

Marshall, L. G., Webb, S. D., Sepkoski, J. J., \& Raup, D. M. (1982). Mammalian evolution and the great american interchange. Science, 215, 1351-1357.

McArthur, J. M. (1994). Recent trends in strontium isotope stratigraphy. Terra Nova, 6(4), 331-358.

McArthur, J. M., Howarth, R. J., \& Bailey, T. R. (2001). Strontium isotope stratigraphy: LOWESS Version 3: Best-fit line to the marine Sr-isotope curve for 0-509 Ma and accompanying lookup table for deriving numerical age. The Journal of Geology, 109(2), 155-170.

Montes, C., Bayona, G., Cardona, A., Buchs, D. M., Silva, C. A., Morón, S., Hoyos, N., Ramirez, D. A., Jaramillo, C. A., Valencia, V. (2012). Arc-continent collision and orocline formation: Closing of the central american seaway. Journal of Geophysical Research, 117(B4).

Montes, C., Cardona, A., McFadden, R., Moron, S. E., Silva, C. A., Restrepo-Moreno, S., et al. (2012b). Evidence for middle Eocene and younger emergence in central Panama: Implications for isthmus closure. Geological Society of America Bulletin, 124(5-6), 780-799.

Muessig, K. W. (1984). Structure and Cenozoic tectonics of the Falcón Basin, Venezuela, and adjacent areas. Geological Society of America Memoirs, 162, 217-230.

Negri, F.R., Bocquentin-Villanueva, J., Ferigolo, J., Antoine, P.O. (2010). A review of the tertiary mammal faunas and birds from western Amazonia. In Amazonia: Landscape and species evolution. 243-258.

Olsson, A.A., \& Richards, H.G. (1961). Some tertiary fossils from the Goajira Peninsula. Acad. Nat. Sci. Phila, Notulae Naturae, 350.

Ortiz, J., Moreno, C., Punyasena, S. W., Cardenas, A. L., \& Jaramillo, C. (2013). SDAR a new quantitative toolkit for analyze stratigraphic data. Houston: NAMS-III.

Peterman, Z. E., Hedge, C. E., \& Tourtelot, H. A. (1970). Isotopic composition of strontium in sea water throughout Phanerozoic time. Geochimica et Cosmochimica Acta, 34(1), 105-120.

Pin, C., \& Bassin, C. (1992). Evaluation of a strontium-specific extraction chromatographic method for isotopic analysis in geological materials. Analytica Chimica Acta, 269(2), 249-255.
Pindell, J. L. (1991). Geologic rationale for hydrocarbon exploration in the Caribbean and adjacent regions. Journal of Petroleum Geology, 14(2), 237-258.

Pindell, J.L., \& Barret, S.F. (1990). Geological evolution of the Caribbean region: A plate tectonic perspective. In G. Dengo \& J. Case (Eds.), The Caribbean region: Boulder, Colorado, Geological Society of America, The Geology of North America (v. H, pp. 405-432).

Qari, M. H. T., Madani, A. A., Matsah, M. I. M., \& Hamimi, Z. (2008). Utilization of Aster and Landsat data in geologic mapping of basement rocks of Arafat Area, Saudi Arabia. The Arabian Journal for Science and Enginering, 33(1C), 99-116.

Quiroz, L., \& Jaramillo, C. (2010). Stratigraphy and sedimentary environments of Miocene shallow to marginal marine deposits in the Urumaco Trough, Falcon Basin, western Venezuela. In M. Sánchez-Villagra, O. Aguilera \& A.A. Carlini (Eds.), Urumaco and Venezuelan Palaeontology. The fossil record of the Northern Neotropics (pp. 153-172). Bloomington: Indiana University Press.

R Development Core Team (2013). R: A language and environment for statistical computing. R Foundation for Statistical Computing, Vienna, Austria. http://www.R-project.org/.

Rawashdeh, S.A., Saleh, B., \& Hamzah, M. (2006). The use of remote sensing technology in geological investigation and mineral detection in El Azraq-Jordan. Cybergeo: European Journal of Geography.

Renz, O. (1960). Geología de la parte sureste de la peninsula de La Guajira. III Congreso Geológico Venezolano, Boletín de Geología, Publicación Especial, Ministerio de Minas e Hidrocarburos, 3(1), 317-347.

Rey, O. (1996). Estratigrafía de la Península de Paraguaná, Venezuela: Revista de la Facultad de Ingeniería, 11, 35-45.

Ribeiro, A.M., Madden, R.H., Negri, F.R., Kerber, L., Hsiou, A.S., \& Rodrigues, K.A. (2013). Brandoni, D. \& Noriega, J.I. (eds). Mamíferos fósiles y biocronología en el suroeste de la Amazonia, Brasil. In: El Neógeno de la Mesopotamia Argentina (pp. 207-221). Buenos Aires, Asociación Paleontológica Argentina.

Rincón, D., Arenas, J. E., Cuartas, C. H., Cárdenas, A. L., Molinares, C. E., Caicedo, C., \& Jaramillo, C. (2007). Eocene-Pliocene planktonic foraminifera biostratigraphy from the continental margin of the southwest Caribbean. Stratigraphy, 4(4), 261-311.

Rincon, A. F., Bloch, J. I., MacFadden, B. J., \& Jaramillo, C. A. (2013). First central American record of Anthracotheriidae (Mammalia, Bothriodontinae) from the early Miocene of Panama. Journal of Vertebrate Paleontology, 33(2), 421-433.

Rincon, A. F., Bloch, J. I., Suarez, C., MacFadden, B. J., \& Jaramillo, C. A. (2012). New Floridatragulines (Mammalia, Camelidae) from the Early Miocene Las Cascadas Formation, Panama. Journal of Vertebrate Paleontology, 32(2), 456-475.

Rollins, J. F. (1965). Stratigraphy and structure of the Goajira Peninsula, northwestern Venezuela and northeastern Colombia. University of Nebraska Studies, 30, 1-102.

Sánchez-Villagra, M. R. (2006). Vertebrate fossils from the Neogene of Falcon State, Venezuela: Contributions on Neotropical Palaeontology. Journal of Systematic Palaeontology, 4(3), 211.

Sánchez-Villagra, M. R., \& Aguilera, O. A. (2006). Neogene vertebrates from Urumaco, Falcon State, Venezuela: Diversity and significance. Journal of Systematic Palaeontology, 4(3), 213-220.

Sánchez-Villagra, M. R., Aguilera, O., \& Horovitz, I. (2003). The anatomy of the world's largest extinct rodent. Science, 301(5640), 1708-1710.

Sánchez-Villagra, M. R., \& Clack, J. A. (2004). Fossils of the miocene castillo formation, venezuela: Contributions on 
neotropical Paleontology. Paleontological Association, Special Papers in Palaeontology, 71, 1-112.

Schetselaar, E. M., Harris, J. R., Lynds, T., \& de Kemp, E. A. (2007). Remote Predictive Mapping 1. Remote Predictive Mapping (RPM): A strategy for geological mapping of Canada's North. Geoscience Canada, 34(3), 93-111.

Sepulchre, P., Arsouze, T., Donnadieu, Y., Dutay, J.-C., Jaramillo, C., Le Bras, J., et al. (2014). Consequences of shoaling of the central American seaway determined from modeling $\mathrm{Nd}$ isotope. Paleoceanography, 29(3), 176-189.

Slaughter, B. H. (1981). A new genus of geomyoid rodent from the Miocene of Texas and Panama. Journal of Vertebrate Paleontology, 1(1), 111-115.

Stehli, F. G., \& Webb, D. S. (1985). The great American biotic interchange. New York: Plenum.

Tejada-Lara, J., Salas-Gismondi, R., Pujos, F., Baby, P., Benammi, M., Brusset, S., De Franceschi, D., Espurt, N., Urbina, M., Antoine, P.O. (2014) Life in proto-Amazonia: middle Miocene mammals from the Fitzcarrald Arch (Peruvian Amazonia). Paleontology, in press.

Thomas, D.J. (1972). The tertiary geology and systematic paleontology (Phylum Mollusca) of the Guajira Peninsula, Colombia, South America. Doctoral Thesis, State University of New York, Binghamton, USA.

Van der Meer, F. D., van der Werff, H. M. A., van Ruitenbeek, F. J. A., Hecker, C. A., Bakker, W. H., Noomen, M. F., et al. (2012). Multi-and hyperspectral geologic remote sensing: A review. International Journal of Applied Earth Observation and Geoinformation, 14(1), 112-128.

Verzi, D. H., \& Montalvo, C. I. (2008). The oldest South American Cricetidae (Rodentia) and Mustelidae (Carnivora): Late miocene faunal turnover in central Argentina and the great American biotic interchange. Palaeogeography, Palaeoclimatology, Palaeoecology, 267(3), 284-291.

Vokes, H. E., \& Vokes, E. H. (1968). Variation in the genus Orthaulax (Mollusca: gastropoda). Tulane Study in Geology and Paleontology, 6, 71-79.

Vucetich, M. G., Carlini, A. A., Aguilera, O., \& Sánchez-Villagra, M. R. (2010). The tropics as reservoir of otherwise extinct mammals: the case of rodents from a new Pliocene faunal assemblage from northern Venezuela. Journal of Mammalian Evolution, 17(4), 265-273.
Wallace, A. R. (1876). The geographical distribution of animals. With a study of the relations of living and extinct faunas as elucidating the Past changes of the Earth's surface. London: Macmillan \& Company.

Webb, S. D. (1976). Mammalian faunal dynamics of the great American interchange. Paleobiology, 2(3), 220-234.

Webb, S.D. (1985). Late Cenozoic mammal dispersal between the Americas. In: Stehli, F.G \& Webb, S.D. (eds). The Great American biotic interchange. New York and London. Plenum Press, 357-386.

Webb, S. D. (1991). Ecogeography and the Great American Interchange. Paleobiology, 17(3), 266-280.

Webb, S. D. (2006). The Great American biotic interchange: patterns and processes. Annals of the Missouri Botanical Garden, 93(2), 245-257.

Whitmore, F. C., \& Stewart, R. H. (1965). Miocene mammals and central American seaways. Science, 148(3667), 180-185.

Wickman, F. E. (1948). Isotope ratios: A clue to the age of certain marine sediments. The Journal of Geology, 56(1), 61-66.

Winkler, J. D., \& Sánchez-Villagra, M. R. (2006). A nesting site and egg morphology of a Miocene turtle from Urumaco, Venezuela: evidence of marine adaptations in a Pelomedusoides. Palaeontology, 49(3), 641-646.

Woodburne, M. O. (2010). The Great American biotic interchange: dispersals, tectonics, climate, sea level and holding pens. Journal of Mammalian Evolution, 17(4), 245-264.

Woodring, W.P. (1957). Geology and paleontology of Canal Zone and adjoining parts of Panama; Geology and description of Tertiary Mollusks. US Geol. Surv. Prof. Paper, 306 A, 1-145.

Zachos, J., Pagani, M., Sloan, L., Thomas, E., \& Billups, K. (2001). Trends, rhythms, and aberrations in global climate $65 \mathrm{Ma}$ to present. Science, 292(5517), 686-693.

Zapata, V. (2010). Estratigrafía de las Unidades Sedimentarias del Paleogeno Superior y Neogeno en la Alta Guajira, Colombia. Master Thesis, Universidad Nacional de Colombia.

Zapata, S., Cardona, A., Montes, C., Valencia, V., Vervoort, J., \& Reiners, P. (2014). Provenance of the Eocene soebi blanco formation, Bonaire, Leeward Antilles: Correlations with postEocene tectonic evolution of northern South America. Journal of South American Earth Sciences, 52(2014), 179-193. 